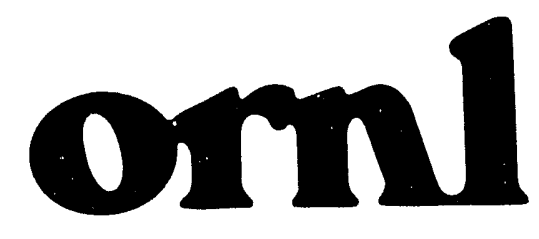

OAK RIDGE

NATIONAL

LABORATORY

MARTIN MARIETTA
ORNL/TM-11798

\section{Development Studies for the Treatment of ORNL Low-Level Liquid Waste}

D. O. Campbell

D. D. Lee

T. A. Dillow 
This report has been reproduced directly from the best available copy.

Available to DOE and DOE contractors from the Office of Scientific and Technical Information, P.O. Box 62. Oak Ridge, TN 37831; prices available from (615) 576-8401, FTS 626-8401.

Available to the public from the National Technical Information Service, U.S. Department of Commerce, 5285 Port Royal Rd., Springfield, VA 22161.

This report was prepared as an account of work sponsored by an agency of the United States Government. Neither the United States Government nor any agency thereof, nor any of their employees, makes any warranty, express or implied, or assumes any legal liability or responsibility for the accuracy, completeness, or usefulness of any information, apparatus, product, or process disclosed, or represents that its use would not infringe privately owned rights. Reference herein to any specific commercial product, process, or service by trade name, trademark, manufacturer, or otnerwise, does not necessarily constifute or imply its endorsement, recommendation, or favoring by the United States Government or any agency thereot. The views and opinions of authors expressed herein do not necessarily state or reflect those of the United States Government or any agency thereof. 
Chemical Technology Division

\section{DEVELOPMENT STUDIES FOR THE TREATMENT OF ORNL LOW-LEVEL LIQUID WASTE}

D. O. Campbell

D. D. Lee

T. A. Dillow

Date Published - November 1991

Prepared for the

Office of Environmental Restoration and Waste Management

(EW 302002 1)

Prepared by the

OAK RIDGE NATIONAL LABORATORY

Oak Ridge, Tennessee 37831

managed by

MARTIN MARIETTA ENERGY SYSTEMS, INC.

for the

U.S. DEPARTMENT OF ENERGY

under contract DE-AC05-84OR21400 


\section{CONTENTS}

LIST OF TABLES $\ldots \ldots \ldots \ldots \ldots \ldots \ldots \ldots \ldots \ldots \ldots \ldots \ldots \ldots \ldots \ldots \ldots \ldots \ldots$

LIST OF FIGURES $\ldots \ldots \ldots \ldots \ldots \ldots \ldots \ldots \ldots \ldots \ldots \ldots \ldots \ldots \ldots \ldots$

ACRONYMS AND INITIALISMS $\ldots \ldots \ldots \ldots \ldots \ldots \ldots \ldots \ldots \ldots \ldots \ldots \ldots$

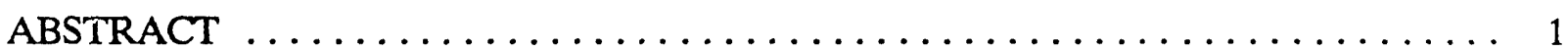

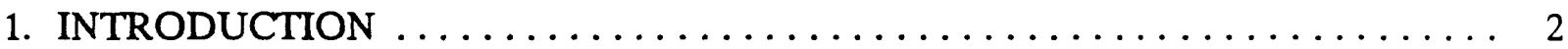

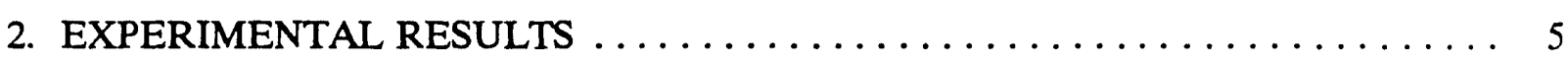

2.1 TESTS WITH INORGANIC SORBENTS. . . . . . . . . . . . 5

2.1.1 Experimental Methods ...................... 5

2.1.2 Removal of Cesium from Simulant Solutions with Inorganic

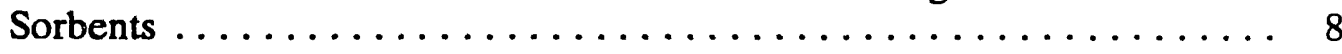

2.1.2.1 Effect of High Alkali-Metal Concentrations . . . . . . . . 8

2.1.2.2 Effects of Cesium Concentration and Ferrocyanide Dosage ..... . 9

2.1.2.3 Removal of Cesium from High-pH Solutions with Dried KCoFC 12

2.1.2.4 Removal of Cesium with Other Transition-Metal Ferrocyanides. . 17

2.1.2.5 Removal of Cesium from Acid Solutions with Ferrocyanides ... . 18

2.1.3 Removal of Cesium from MVST Supernate Solutions with Inorganic

Sorbents ............................. 19

2.1.4 Removal of Strontium from Simulant Solutions with Inorganic Sorbents . 23

2.2 SIMULANT DECONTAMINATION WITH ORGANIC ION-EXCHANGE

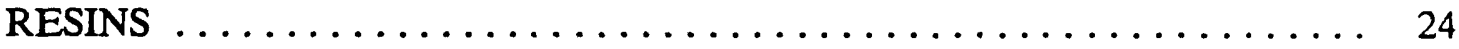

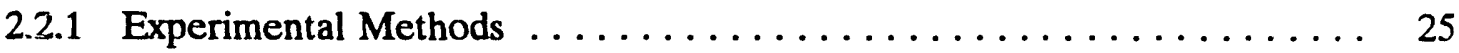

2.2.2 Cesium and Strontium Removal with Chelating Resins ......... 26

2.2.2.1 Batch Tests ....................... 26

2.2.2.2 Simultaneous Cesium and Strontium Removal with Mixed-Resin

Column ........................... 29

2.2.3 Source Treatment Studies of Aluminum Decladding Solutions . . . . . . 29

2.3 CROSS-FLOW FILTRATION TESTS $\ldots \ldots \ldots \ldots \ldots \ldots \ldots \ldots \ldots \ldots$

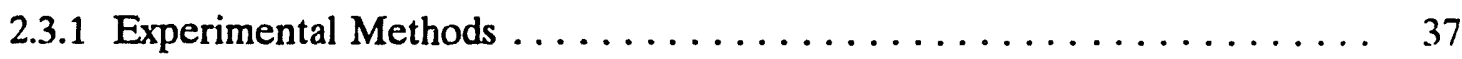

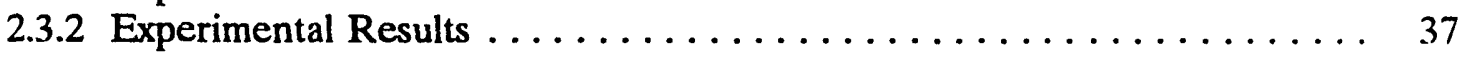

2.4 REMOVAL OF ${ }^{60}$ Co FROM SUPERNATE $\ldots \ldots \ldots \ldots \ldots \ldots \ldots \ldots$

2.4 .1 Experimental Methods ........................ 38

2.4 .2 Experimental Results . . . . . . . . . . . . . . . . 38

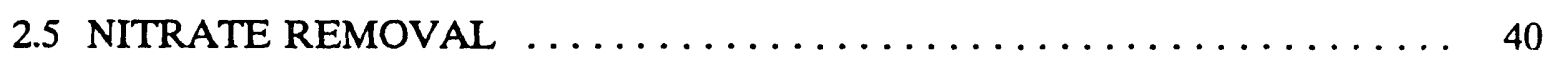

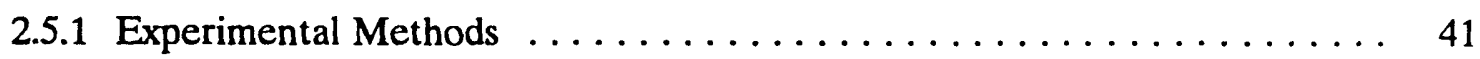

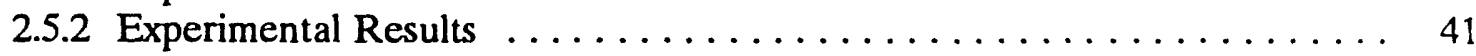

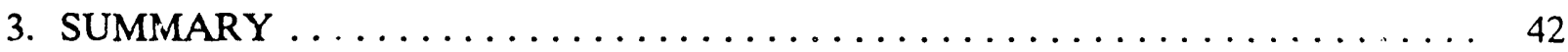

4. REFERENCES ............................... 44 


\section{LIST OF TABLES}

Table

Page

1 Effects of sodium and potassium concentrations on cesium removal . . . . . . 9

2 Effect of cesium concentration on cesium $\mathrm{K}_{d}$ from W-29 simulant at $\mathrm{pH} 10 \ldots 10$

3 Effects of cesium concentration, $\mathrm{pH}$, and $\mathrm{NaNiFC}$ concentration on cesium

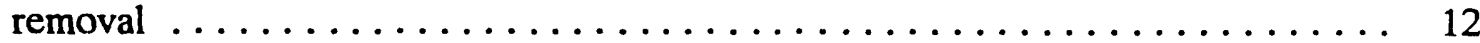

4 Distribution coefficients of $\mathrm{KCoFC}$ and $\mathrm{NaCoFC}$ at different sorbent loadings . . 13

5 Percent removal of cesium at high $\mathrm{pH}$ with granular $\mathrm{KCoFC} \ldots \ldots \ldots \ldots \ldots$

6 Cesium distribution coefficients at high $\mathrm{pH}$ with granular $\mathrm{KCoFC} \ldots \ldots \ldots \ldots 16$

7 Cesium distribution coefficients at high $\mathrm{pH}$ with commercial $\mathrm{KCoFC} \ldots \ldots \ldots 16$

8 Cesium distribution coefficients with granular KCuFC (100-200 mesh, 333 ppm)

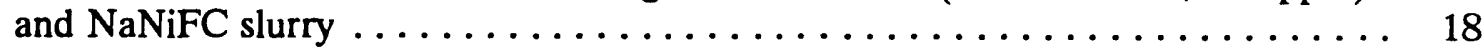

9 Cesium distribution coefficients for acidified solutions with $100 \mathrm{ppm}$ ferrocyanides 20

10 Cesium removal from acid solutions with $100 \mathrm{ppm} \mathrm{NaNiFC}$ at 4-d contact time . 21

11 Test of three-stage batch separation of ${ }^{137} \mathrm{Cs}$ from $\mathrm{W}-26$ supernate $\ldots \ldots \ldots \ldots 22$

12 Strontium removal from $W-29$ simulant with inorganic sorbents $\ldots \ldots \ldots \ldots .24$

13 Batch $\mathrm{Sr}$ and $\mathrm{Cs} \mathrm{K}_{\mathrm{d}} \mathrm{s}$ with simulant $(\mathrm{Na}=4.58 \underline{\mathrm{M}}, \mathrm{K}=0.25 \underline{\mathrm{M}}, \mathrm{pH}=12.9,150$

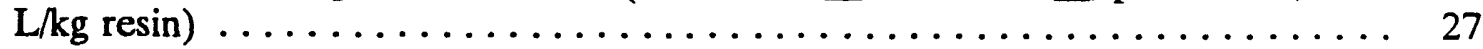

14 Batch strontium and cesium $\mathrm{K}_{\mathrm{d}}$ data for chelating and SRS resins (phase ratio:

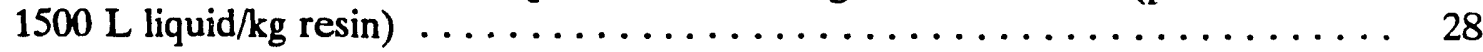

15 Expected composition of aluminum target dissolution waste $\ldots \ldots \ldots \ldots \ldots 2$

16 Cesium and strontium removal from caustic aluminate solution with inorganic

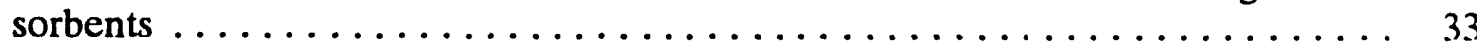

17 Comparison of 60-80 mesh with 120-140 mesh SRS resin using simulated

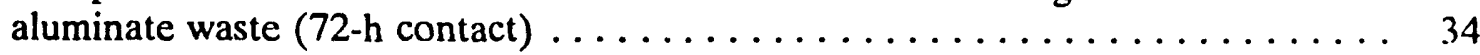

18 Removal of cesium and strontium from simulated aluminate waste using $60-80$

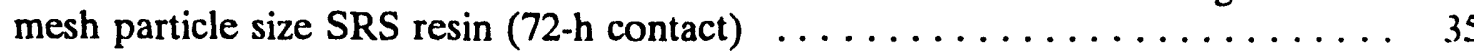

Figure

\section{LIST OF FIGURES}

1 Breakthrough curves for mixed IRC-718 plus SRS resin column $\ldots \ldots \ldots \ldots$ 


\section{ACRONYMS AND INITIALISMS}

CV

DF

DOE

$\mathrm{KCoFC}$

$\mathrm{KCuFC}$

$\mathrm{K}_{\mathrm{d}}$

LLLW

MVSTs

MWCO

$\mathrm{NaCoFC}$

$\mathrm{NaNiFC}$

$\mathrm{NaT}$

ORNL

ppm

REDC

TRU

WHPP
Column volumes

Decontamination factor $\left(\mathrm{C}_{0} / \mathrm{C}\right)$

U.S. Department of Energy

Potassium cobalt ferrocyanide

Potassium copper ferrocyanide

Distribution coefficient

Low-level (radioactive) liquid waste

Melton Valley Storage Tanks

Molecular weight cutoff

Sodium cobalt ferrocyanide

Sodium nickel ferrocyanide

Sandia sodium titanate

Oak Ridge National Laboratory

Parts per million (amount of sorbent)

Radiochemical Engineering Development Center

Transuranic (waste)

Waste Handling and Packaging Plant 


\title{
DEVELOPMENT STUDIES FOR THE TREATMENT OF ORNL LOW-LEVEL LIQUID WASTE
}

\author{
D. O. Campbell \\ D. D. Lee \\ T. A. Dillow
}

\begin{abstract}
An experimental program is under way to investigate potential separation methods for application to specific problems relating to the management of low-level liquid wastes (LLLWs) at ORNL. This report summarizes experimental results that were acquired during fiscal year 1990 and have not been previously reported elsewhere. Measurements are presented for cesium and strontium removal from simulated high-salt wasic compositions, using both inorganic ion-exchange sorbents and organic ion-exchang,e resins, and for one experiment with actual LLLW supernate solution from Melton Valley Storage Tank W-26, using inorganic sorbents. The purpose of the study was to acquire an extensive data base to support the development of flowsheets for decontamination of the LLLW currently stored at ORNL.

Experimental measurements with inorganic ion exchangers focused on batch separations of cesium using several transition-metal hexacyanoferrate(II) compositions (ferrocyanides) and of strontium using titanium oxide-based sorbents. Cesium distribution coefficients in the range of $1 \times 10^{6}$ were generally observed with nickel and cobalt ferrocyanides at $\mathrm{pH}$ values $\leq 11$, yielding DFs of about 100 with $100 \mathrm{ppm}$ sorbent in a single-stage batch separation. The ferrocyanides decompose at higher $\mathrm{pH}$ levels, but certain compositions can be stabilized by heat treatment and will maintain their effectiveness up to $\mathrm{pH} 13$ for times of a few days. Ferrocyanides are stable in acid solutions and remain reasonably effective as the $\mathrm{pH}$ decreases into the acid concentration range of at least 1-2 $\underline{\mathrm{M}}$. Strontium distribution coefficients as large as $1 \times 10^{5}$ were observed with sodium titanate at $\mathrm{pH} \mathrm{13}$, but these values decrease as the $\mathrm{pH}$ decreases.

Most organic ion-exchange resins are not very effective for cesium removal from such high salt concentrations, but a new resorcinol-based resin developed at the Savannah River Site was found to be considerably superior to any other such material tested. An unexpected effect of resin particle size was observed; that is, the larger resin particles showed more effective cesium removal than did the small particles. Several chelating resins were effective for removing strontium (along with other polyvalent ions) from the waste simulants. An ion-exchange column test successfully demonstrated the simultaneous removal of both cesium and strontium from a waste simulant solution.
\end{abstract}


The large distribution coefficients and poor physical form (degradation to small particles) of most inorganic sorbents favor their use in simple batch separation processes. Although distribution coefficients were smaller with organic resins than with the best inorganic sorbents, they were large enough, in some cases, to make batch processes possible. However, organic resins are generally more suited to column operations, and the distribution coefficients for these materials were entirely adequate for this application.

Experiments using ultrafiltration for particulate removal are described. Various methodologies were explored to remove ${ }^{60} \mathrm{Co}$ from supernate, including ion exchange and ultrafiltration. Scouting experiments are also described for nitrate removal from simulant.

\section{INTRODUCTION}

An experimental program was initiated to investigate potential separation methods for application to specific problems relating to the management of low-level liquid wastes (LLLWs) at ORNL. The wastes of particular concern include the contents of the Melton Valley Storage Tanks (MVSTs) and similar tanks associated with the LLLW evaporator, currently and future generated LLLW that is being, or will be, added to the MVSTs, and residual wastes in the inactive storage tanks that might be transferred to the MVSTs. Some of the methods under study may also be applicable to treatment of the process waste and of certain wastes at the point of generation - before they are diluted into and contaminate a large volume and are mixed with other constituents, creating a waste that is more difficult to treat.

At the beginning of this study, it was known that the major radioactive constituents in these wastes were alpha-emitting actinides, ${ }^{137} \mathrm{Cs}$, and ${ }^{90} \mathrm{Sr}$. Tank sampling indicated that the alpha content of the supernate was generally below the $100-\mathrm{nCi} / \mathrm{g}$ limit for transuranium (TRU) waste. Accordingly, the study was focused on removal of cesium and strontium from the supernate. The primary emphasis was placed on cesium removal because the activity level of cesium was higher than that of any other radionuclide; in addition, since it is the dominant gamma-emitter, its removal would allow subsequent waste processing operations (further decontamination, concentration, solidification, and transportation) to be conducted without the necessity of contending with a high gamma field. More recent analyses ${ }^{1}$ have indicated that, although these are clearly the most significant activities, other constituents must also be considered, depending on the final disposition of the waste. These include 
${ }^{60} \mathrm{Co},{ }^{14} \mathrm{C}$, nitrate, RCRA ${ }^{*}$ metals, and possibly others. The implications of these analyses and evolving specifications for liquid and solid wastes are considered in another report which is now in preparation. ${ }^{2}$

The objective, then, was to develop processes to remove cesium, strontium, and (if necessary) actinides from the waste supernate, thereby allowing the supernate to be disposed of on-site (either as a solid waste after treatment or possibly as a liquid discharge after adequate decontamination). The specific initial goals were (1) the separation of cesium and (2) the separation of strontium from alkaline solutions containing high concentrations of $\mathrm{NaNO}_{3}$, moderate concentrations of $\mathrm{KNO}_{3}$, and low concentrations of several other ions. Removal of enough supernate in this manner would reduce the volume of waste contained in the existing tanks so that they would be adequate to contain all of the LLLW sludge, which is a TRU waste, until the Waste Handling and Packaging Plant $^{3}$ (WHPP) is built to process the accumulated LLLW for ship.nent to the Waste Isolation Pilot Plant. An alternative process to provide additional sludge storage capacity, direct solidification of supernate (without decontamination) into solid monoliths, has been used once and may be used subsequently. Decontamination of the supernate prior to solidification would reduce the radiation level and, therefore, the handling and disposal problems associated with these solid wastes.

The fundamental premise underlying this approach is that there is an inherent benefit if the waste can be divided into fractions of differing potential hazard. In this way, the quantity of more-hazardous waste is greatly reduced while the bulk of the waste is made much less hazardous, thereby meeting requirements for storage and disposal with less restrictive conditions or possibly even environmental release. This is possible, in principle, because the elements containing radioactive isotopes constitute only a small fraction of the total quantity of waste. The bulk components in the supernate are primarily water and salts such as $\mathrm{NaNO}_{3}$ and $\mathrm{KNO}_{3}$.

Two general approaches have been followid in this study. One is the use of inorganic ion-exchange sorbents that have remarkably high affinity for the elements of interest. These reagents can be added during batch clarification or scavenging precipitation processes to enhance the removal of a variety of elements. Such processes are commonly used in Europe for treating low- and intermediate-level wastes. ${ }^{4}$ The other approach is

'Resource Conservation and Recovery Act. 
conventional ion-exchange column separations using organic resins, which are commonly used for treating relatively pure (low-salt-content) water but are less satisfactory for high-salt solutions.

Based largely on an extensive literature base and experience with waste processing primarily in Europe ${ }^{5-7}$ which are not reviewed here, the transition-metal hexacyanoferrate(II) compounds and formulations based on titanium oxide were selected as the primary candidates for cesium and strontium removal, respectively. Many other materials were considered but were concluded to be less promising for various reasons. Several zeolites have been used successfully for decontaminating water of relatively low salt content from both cesium and strontium, but they have little capacity with these LLLW solutions. Tetraphenyl borate has been used successfully for cesium removal; however, it is subject to serious interference from potassium, which is a major constituent in some MVST tanks; it also has secondary environmental problems. A new material, cobalt dicarbolyde, ${ }^{8}$ has recently been proposed, but it is currently very expensive and not well documented. An extensive literature review revealed that several inorganic sorbents (i.e., titanates, niobates, tungstates, titanium phosphate, zirconium phosphate, polyantimonic acid) have been shown to remove strontium under some conditions. These sorbents do not efficiently separate strontium from calcium, an important metal in the MVSTs; however, a new solvent extraction process, SREX, ${ }^{9,10}$ has been shown to separate strontium from most metals, even from the other alkaline earths. Studies of cesium removal with organic resins have centered on a new resin developed at the Savannah River Site specifically for cesium removal. ${ }^{11,12}$ At the same time, other organic resins suitable for removing other elements of concern (notably strontium) are being tested.

Prior experimental results have been presented in a letter report, ${ }^{13}$ and a paper has been published in the Proceedings of the Waste Management ' 90 Conference. ${ }^{14}$ These reports summarize extensive data covering the anticipated range of application of these sorbents to a MVST simulant solution. Additional experimental data are given in this report, much of which concerns extension of the study to a wider variation of conditions to establish more definitively the range of applicability of the inorganic sorbents. These studies include the removal of cesium and strontium from various solutions by use of both inorganic sorbents and organic ion-exchange resins. A wide range of conditions has been investigated because of the large variations that are anticipated in various waste streams that might be processed. In addition, a multistage, batch cesium-removal test with MVST W-26 supernate is reported. 


\section{EXPERIMENTAL RESULTS}

\subsection{TESTS WITH INORGANIC SORBENTS}

\subsection{Experimental Methods}

All the data with inorganic sorbents have been obtained from batch contacts of the sorbent with the appropriate solution. Unless otherwise noted, a simulant solution derived from analysis of MVST W-29 was used; the W-29 simulant contained 3.9 $\underline{\mathrm{M} \mathrm{NaNO}} 3,0.25 \underline{\mathrm{M}}$ $\mathrm{KNO}_{3}, 0.24 \underline{\mathrm{M}} \mathrm{NaOH}, 0.14 \underline{\mathrm{M}} \mathrm{Na}_{2} \mathrm{CO}_{3}, 0.1 \underline{\mathrm{M} \mathrm{NaCl}}, 0.001 \underline{\mathrm{M}} \mathrm{Zn}\left(\mathrm{NO}_{3}\right)_{2}, 0.0005 \underline{\mathrm{M}}$ $\mathrm{Al}\left(\mathrm{NO}_{3}\right)_{3}$, and $0.0001 \underline{\mathrm{M} \mathrm{CaCO}}$. The MVST tanks differed somewhat in overall composition; however, the potassium, calcium, carbonate, and acid concentrations varied by large factors. The W-29 simulant solution was spiked with cesium using a small amount of actual W-29 supernate $\left({ }^{137} \mathrm{Cs}\right.$ predominant) and with strontium using ${ }^{85} \mathrm{Sr}$ tracer. Solutions were adjusted to the specified $\mathrm{pH}$ prior to the test, and usually the $\mathrm{pH}$ was checked again afterward; in most cases, the changes were small. Orion Research Model SA 520 and 811 $\mathrm{pH}$ meters were used. Some difficulty was encountered with $\mathrm{pH}$ determinations in the solutions of high $\mathrm{Na}^{+}$and high $\mathrm{pH}$, but the problem was traced to a certified $\mathrm{pH}$ standard that was in error. It was difficult to adjust to and maintain a stable $\mathrm{pH}$ in an experiment using actual MVST W-26 supernate, which was very low in carbonate ion; the addition of $\sim 0.001 \mathrm{M} \mathrm{Na} \mathrm{CO}_{3}$ alleviated this problem.

A sorbent and a solution were mixed in 15-mL centrifuge cones using a "Roto-Torque" rotating mixer. The rotational speed and tilt angle were adjusted, by experiment, to give good mixing even with fairly large sorbent particles. After being mixed for predetermined times, the cones were removed and (unless stated otherwise) centrifuged prior to sampling. Variations in the clarification procedure included sedimentation, filtration, centrifugation following filtration, and double centrifugation.

Filtration was accomplished with 4-mm-diam Nalgene filter discs of cellulose acetate, $0.2-\mu \mathrm{m}$ pore size. Centrifugation was carried out in $15-\mathrm{mL}$ centrifuge tubes using a 30-cm-diam IEC HN SII centrifuge. In most of the work, polypropylene tubes were used at $2600 \mathrm{rpm}$. Glass wentrifuge tubes were used in the initial work, but they occasionally broke at $2600 \mathrm{rpm}$; as a result, they were centrifuged at about $2200 \mathrm{rpm}$. In all cases, the samples were centrifuged for approximately $10 \mathrm{~min}$.

Samples of the clarified supernate (usually $1 \mathrm{~mL}$ ) were removed with a pipette and transferred to sample vials for counting. It is often difficult to remove all of the sorbent crystals from the soiutions; in many cases, reclarification led to a lower activity in the 
sample and a higher decontamination factor (DF). Samples were counted using either a $\mathrm{NaI}$ well counter with an LBK Wallack Compugamma analysis system or an intrinsic germanium detector and spectral analysis system. Only relative counts are required in this work, but counters were calibrated against counting standards.

The transition-metal hexacyanoferrate(II) compounds can be prepared and used in several ways. Nearly all the work was concerned with nickel or cobalt ferrocyanide, but some experiments were also performed with the zinc, iron, manganese, and copper compounds. Four methods were used: (1) preparation in situ by adding (while mixing) a specified amount of $0.1 \underline{\mathrm{M}}$ metal nitrate solution, followed by the specified amount of $0.1 \underline{\mathrm{M}}$ $\mathrm{Na}_{4} \mathrm{Fe}(\mathrm{CN})_{6}$ or $\mathrm{K}_{4} \mathrm{Fe}(\mathrm{CN})_{6}$; (2) preparation in situ by adding the reagents in the reverse order; (3) preparation of a slurry by adding the reagents to water and then adding a specified amount of the slurry to the test solution; and (4) adding a weighed amount of solid prepared by filtering, washing, and drying a slurry. In many cases, the procedure of Prout, Russell, and Groh ${ }^{15}$ for preparing KCoFC was followed, substituting the metal of interest for cobalt (hereafter referred to as the Savannah River method). This method was carried to the point of preparing a slurry [for method (3)] or the dried solid [for method (4)]. In some cases, the slurries were diluted with demineralized water so that the volume to be added could be measured more accurately. All data in this report are derived from experiments using preparation method (3) or (4).

The first three methods gave similar results except that the difficulty of clarification varied considerably, depending on the exact procedure followed. Most work was done using the slurry (method 3 ) or a dried material (method 4). The ferrocyanide slurries were readily prepared by mixing a $0.1 \underline{\mathrm{M}}$ solution of $\mathrm{Na}_{4} \mathrm{Fe}(\mathrm{CN})_{6}$ or $\mathrm{K}_{4} \mathrm{Fe}(\mathrm{CN})_{6}$ with a $0.1 \underline{\mathrm{M}}$ solution of the metal salt (nickel or cobalt nitrate); a measured amount of the slurry was then added to the waste solution after $\mathrm{pH}$ adjustment. The ratio of metal to ferrocyanide was generally 1.5 to 1.7 , and some excess metal probably precipitated as $\mathrm{Ni}(\mathrm{OH})_{2}$ or $\mathrm{Co}(\mathrm{OH})_{2}$, which would strongly affect the sedimentation properties. Results of early qualitative tests showed that clarification was more difficult if the metal/ferrocyanide ratio was less than about 1.5 , and precipitate particle sizes are very small at best. However, in practice, lower ratios might be advantageous if solutions are clarified by filtration.

Since the ferrocyanides are usually not stoichiometric or are mixtures of compounds, the actual concentration used is subject to some uncertainty. The composition can be represented as $A_{n} T_{(2-n / 2)} \mathrm{Fe}(\mathrm{CN})_{6}$, where $A$ represents the alkali metal ( $N$ a or $\left.K\right), T$ is the 
transition $\mathrm{mi} . \mathrm{d}(\mathrm{Co}, \mathrm{Ni}$, etc.), and $\mathrm{n}<4$. In this study, concentrations (as ppm, defined as $\mathrm{mg}$ solid/L solution) are calculated by assuming that all the metal $(\mathrm{Ni}$ or $\mathrm{Co}$ ) and all the $\mathrm{Fe}(\mathrm{CN})_{6}{ }^{4-}$ form a precipitate and, in addition, enough of the alkali metal ( $\mathrm{Na}$ or $\mathrm{K}$ ) is included to satisfy valency requirements. In practice, these sorbents do have slight solubilities and a small fraction of the metal may not be included in the compound but, instead, may precipitate as the hydroxide. Also, they are hydrates, which would increase their mass. Most work was carried out with a nominal $100 \mathrm{ppm}$ by adding a pre-prepared

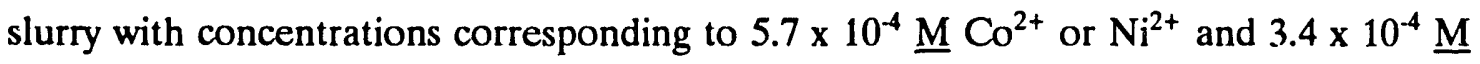
$\mathrm{Fe}(\mathrm{CN})_{6}^{4-}$, which calculate to be 104 and $108 \mathrm{ppm}$ for the $\mathrm{Na}$ and $\mathrm{K}$ compounds, respectively.

I he nickel ferrocyanides and sodium cobalt ferrocyanide ( $\mathrm{NaCoFC}$ ) yield powders when dried, but some compositions (including copper ferrocyanides and potassium cobalt ferrocyanide [KCoFC]) can be prepared as hard, granular material. Nickel ferrocyanides can be prepared as granular solids, out only by a long and tedious process. ${ }^{16}$ The granular solids can be used in ion-exchange columns. ${ }^{17}$ All of these sorbents may be used for cesium removal ov. the $\mathrm{pH}$ range from a maximum of about 11 down to moderately acidic solutions. Above $\mathrm{pH} 11$, the compounds are decomposed and lose effectiveness. This happens rapidly with powders, but granular $\mathrm{KCoFC}$, after proper conditioning, is relatively stable for many hours to severs : days at $\mathrm{pH}$ levels up to $13 .{ }^{17}$ Digestion at high $\mathrm{pH}(>13)$ eventually frees the cesium and ferrocyanide ion, leaving a nickel or cobalt hydroxide precipitate; in this way, the cesium could be recovered for further concentration, if desired.

The sorbents tested for strontium removal (sodium titanate, titanium oxide, hydrous titania, titanium phosphate, and zirconium phosphate) were used as particulate solids. The sodium titanate was obtained several years ago from a development program at the Sandia National Laboratory. ${ }^{18}$ The titanium oxide was Fisher reagent grade. The other materials were gel-derived microspheres made by the internal gelation process and prepared by $\mathrm{J}$. $\mathrm{L}$. Collins (ORNL).

The results of the experimer:" can be expressed by several different parameters that relate to the decontamination effectiveness. The distribution coafficient, which is useful because it is approxintately constant over a reasonable range of conditions, is calculated as:

$$
\mathrm{K}_{\mathrm{d}}=\left(\mathrm{C}_{\mathrm{o}}-\mathrm{C}\right) \mathrm{V} / \mathrm{mC}=10^{6}\left(\mathrm{C}_{\mathrm{o}}-\mathrm{C}\right) / \mathrm{C}(\mathrm{ppm})
$$


where $\mathrm{C}_{\mathrm{o}}$ and $\mathrm{C}$ are the aqueous concentrations $(\mathrm{Bq} / \mathrm{mL})$ of the radioisotope before and after treatment, $\mathrm{m}$ is the mass of sorbent $(\mathrm{g}), \mathrm{V}$ is the volume of wa:te solution $(\mathrm{mL})$, and ppm is the amount of sorbent in parts per million, expressed in this paper as mg sorbent per liter of solution. When successive samples were removed from the same experiment, the values of $C_{o}$ and $V$ were recalculated after each sample was withdrawn, taking into account the measured concentration and volume of the sample withdrawn.

The decontamination factor, as used in this report, is:

$$
\mathrm{DF}=\mathrm{C}_{\mathrm{d}} \mathrm{C}=1+1 \times 10^{-6}(\mathrm{ppm}) \mathrm{K}_{\mathrm{d}}
$$

Defined in this way, the DF includes concentration reduction due to dilution as well as ion exchange, but there are other definitions of DF that can be used, notably the total activity in the feed divided by the total activity in the product.

The reduction of activity (including dilution) can also be expressed as the percent removed:

$$
\% \text { removed }=100\left(C_{o}-C\right) / C_{o}=100(1-1 / D F)=100(p p m) K_{d} /\left[10^{6}+(p p m) K_{d}\right]
$$

In the data reported as DF or as \% removed, the correction for variations in concentration of successive samples has not been made. In effect, this causes the reported "\% removed" to be slightly smaller than the true value in some cases.

\subsection{Removal of Cesium from Simulant Solutions with Inorganic Sorbents}

\subsubsection{Effect of High Alkali-Metal Concentrations}

Characterization data for the MVSTs ${ }^{1}$ indicated that the potassium concentration was much higher in some cases than the $\sim 0.25 \underline{\mathrm{M}}$ expected, up to a maximum of approximately $2 \underline{\mathrm{M}}$ in one tank and $0.5 \underline{\mathrm{M}}$ average in all tanks. Since potassium is the primary interference with cesium removal by most processes, a series of tests was performed to extend both the sodium and potassium concentrations to higher concentrations ( 8 and $1 \underline{\mathrm{M}}$, respectively) than those of the W-29 simulant. Both sodium nickel ferrocyanide (NaNiFC) and $\mathrm{KCoFC}$ were tested as slurries at $50 \mathrm{ppm}$ at pH 9.5 and with mixing times of $3 \mathrm{~h}$ to $4 \mathrm{~d}$. The results (Table 1 ) indicate that NaNiFC is somewhat better, especially at the highest potassium concentration, but both are remarkably effective even with $8 \underline{\mathrm{M} \mathrm{NaNO}_{3}-}$ 
$1 \underline{\mathrm{M}} \mathrm{KNO}_{3}$. The data represent the average of two samples after mixing for $4 \mathrm{~d}$; one sample was centrifuged twice, while the other was centrifuged and then filtered. Samples taken after centrifuging only once (including all samples at shorter contact times) showed comparable or slightly less effective cesium removal.

The NaNiFC compound was somewhat better, especially in cases of high $\mathrm{KNO}_{3}$ and low $\mathrm{NaNO}_{3}$ concentrations. There was an unexpected trend for $\mathrm{KCoFC}$ to be less effective in the lower $\mathrm{NaNO}_{3}$ concentrations than in higher concentrations, but this may be related to clarification rather than ion-exchange properties.

Table 1. Effects of sodium and potassium concentrations on cesium removal

\begin{tabular}{|c|c|c|c|c|c|c|}
\hline \multirow{2}{*}{$\begin{array}{l}\mathrm{Na} \text { conc. } \\
(\underline{\mathrm{M}})\end{array}$} & \multicolumn{3}{|c|}{ \% Removed at: } & \multicolumn{3}{|c|}{$\mathbf{K}_{\text {d at: }}$} \\
\hline & $0.25 \underline{M} \mathrm{~K}$ & $0.50 \underline{\mathrm{M}} \mathrm{K}$ & $1.00 \underline{\mathrm{M}} \mathrm{K}$ & $0.25 \underline{\mathrm{M}} \mathrm{K}$ & $0.50 \underline{\mathrm{M}} \mathrm{K}$ & $1.00 \underline{\mathrm{M} \mathrm{K}}$ \\
\hline \multicolumn{7}{|c|}{50 ppm NaNiFC Slurry } \\
\hline 2 & 99.4 & 98.7 & 97.6 & $3.0 \mathrm{E} 6$ & 1.3E6 & 7.1E5 \\
\hline 4 & 99.1 & 99.1 & 98.2 & 2.0E6 & 2.0E6 & 9.7E5 \\
\hline 8 & 96.5 & 98.3 & 98.0 & $5.7 \mathrm{E} 5$ & $1.1 \mathrm{E} 6$ & $9.1 \mathrm{E} 5$ \\
\hline \multicolumn{7}{|c|}{50 ppm KCoFC Slurry } \\
\hline 2 & 97.9 & 94.7 & 89.7 & 8.3E5 & $3.2 \mathrm{E} 5$ & $1.6 \mathrm{E} 5$ \\
\hline 4 & 99.3 & 99.2 & 91.3 & $2.6 \mathrm{E} 6$ & $2.6 \mathrm{E} 6$ & $1.9 \mathrm{E} 5$ \\
\hline 8 & 98.0 & 98.0 & 98.0 & 9.1E5 & $9.0 \mathrm{E} 5$ & $9.0 \mathrm{E} 5$ \\
\hline
\end{tabular}

\subsubsection{Effects of Cesium Concentration and Ferrocyanide Dosage}

Since significant loadings of ion exchangers can be achieved when very large phase ratios are used, even when the exchanging ion is quite dilute, a test was carried out to determine the effect of cesium concentration on the distribution coefficient. Stable cesium was added to yield concentrations from $2.5 \times 10^{-7}$ to $1 \times 10^{-5} \underline{\mathrm{M}}$ in W-29 waste simulant solution that was traced with W-29 waste supernate. The tracer added a negligible additional cesium concentration (about $1 \times 10^{-9} \underline{\mathrm{M}}$ ). The results (Table 2, upper half) show that the cesium $\mathrm{K}_{\mathrm{d}}$ exceeded $1 \times 10^{6}$ for all mixing times of $1 \mathrm{~d}$ or more over the entire cesium concentration range when $100 \mathrm{ppm} \mathrm{NaNiFC}$ slurry was used. Corresponding cesium removals are generally in excess of $99.5 \%$. With $\mathrm{KCoFC}$, the $\mathrm{K}_{\mathrm{d}} \mathrm{s}$ were generally $<1 \times 10^{6}$. 
Most tests with ferrocyanide slurries have used approximately 100 -ppm dosages. Tests with dried, granular material have used even larger amounts, commonly 333 to $500 \mathrm{ppm}$, because of the difficulty in accurately weighing the small amounts. Earlier tests with ferrocyanides for removing cesium from tap water were reasonably successful with smaller additions, down to $<10 \mathrm{ppm}$. Accordingly, a parallel set of experiments was done with the W-29 simulant solution using slurry additions of $10 \mathrm{ppm}$ of both NaNiFC and KCoFC (Table 2, lower half).

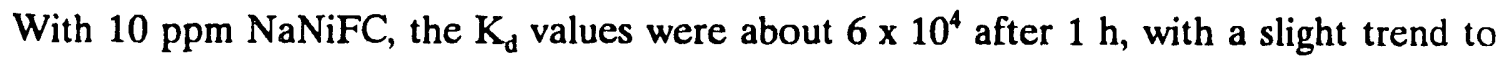
decrease as the cesium concentration increased. However, they decreased to very small values after 1- and 6-d contact times with the lower cesium concentrations but increased somewhat at the highest cesium concentration. With $10 \mathrm{ppm} \mathrm{KCoFC}$, there was no useful cesium removal at any time for cesium concentrations $<2.5 \times 10^{-6} \underline{\mathrm{M}}$; at higher concentrations, however, there was significant cesium removal that increased with time.

Table 2. Effect of cesium concentration on cesium $\mathrm{K}_{d}$ from W-29 simulant at $\mathbf{p H} 10$

\begin{tabular}{|c|c|c|c|c|c|c|}
\hline \multirow[t]{2}{*}{ Cs $(\underline{\mathrm{M}})$} & \multicolumn{3}{|c|}{$\mathrm{K}_{\mathrm{d}}$ at: $100 \mathrm{ppm} \mathrm{NaNiFC}$} & \multicolumn{3}{|c|}{$\mathrm{K}_{\mathrm{d}}$ at: $100 \mathrm{ppm} \mathrm{KCoFC}$} \\
\hline & $1 \mathrm{~h}$ & $1 \mathrm{~d}$ & $6 d^{2}$ & $1 \mathrm{~h}$ & $1 \mathrm{~d}$ & $6 \mathrm{~d}^{\mathrm{a}}$ \\
\hline $2.5 \mathrm{E}-7^{\mathrm{b}}$ & $5.0 \mathrm{E} 5$ & $1.3 \mathrm{E} 6$ & $3.2 \mathrm{E} 6$ & $8.3 \mathrm{E} 5$ & $4.1 \mathrm{E5}$ & $7.5 \mathrm{E} 5^{\mathrm{c}}$ \\
\hline $5.0 \mathrm{E}-7$ & $7.2 \mathrm{E} 5$ & 2.0E6 & 2.1E6 & $7.2 \mathrm{E} 5$ & $3.8 \mathrm{E} 5$ & $5.8 \mathrm{E5}^{\mathrm{c}}$ \\
\hline $1.0 \mathrm{E}-6$ & $5.2 \mathrm{E} 5$ & $1.7 \mathrm{E} 6$ & $2.0 \mathrm{E} 6$ & $5.3 \mathrm{E} 5$ & $3.8 \mathrm{E} 5$ & $8.2 \mathrm{E} 5^{\mathrm{c}}$ \\
\hline $2.5 \mathrm{E}-6$ & $7.2 \mathrm{E} 5$ & $1.2 \mathrm{E} 6$ & $3.3 \mathrm{E} 6^{\mathrm{c}}$ & $4.9 \mathrm{E} 5$ & $3.6 \mathrm{E} 5$ & $8.1 \mathrm{E} 5^{c}$ \\
\hline $5.0 \mathrm{E}-6$ & $7.0 \mathrm{E} 5$ & $1.8 \mathrm{E} 6$ & $3.6 \mathrm{E} 6^{\mathrm{c}}$ & $4.8 \mathrm{E} 5$ & $4.6 \mathrm{E} 5$ & $8.8 \mathrm{E} 5^{\mathrm{c}}$ \\
\hline \multirow[t]{3}{*}{$1.0 \mathrm{E}-5$} & $6.5 \mathrm{E} 5$ & $1.5 \mathrm{E} 6$ & $3.4 \mathrm{E} 6^{\mathrm{c}}$ & $4.4 \mathrm{E} 5$ & $4.0 \mathrm{E} 5$ & $1.0 \mathrm{E} 6^{\mathrm{c}}$ \\
\hline & \multicolumn{3}{|c|}{10 ppm NaNiFC } & \multicolumn{3}{|c|}{10 ppm KCoFC } \\
\hline & $1 \mathrm{~h}$ & $1 \mathrm{~d}$ & $6 d^{2}$ & $1 \mathrm{~h}$ & $1 \mathrm{~d}$ & $6 \mathrm{~d}^{\mathrm{a}}$ \\
\hline $\begin{array}{l}2.5 \mathrm{E}-7 \\
5.0 \mathrm{E}-7 \\
1.0 \mathrm{E}-6 \\
2.5 \mathrm{E}-6\end{array}$ & $\begin{array}{l}7.3 \mathrm{E} 4 \\
6.3 \mathrm{E} 4 \\
6.3 \mathrm{E} 4 \\
4.4 \mathrm{E} 4\end{array}$ & $\begin{array}{l}\approx 1 \\
\approx 1 \\
\approx 1 \\
2.1 \mathrm{E} 4\end{array}$ & $\begin{array}{c}\approx 1 \\
\approx 1 \\
\approx 1 \\
9.1 \mathrm{E} 3\end{array}$ & $\begin{array}{c}3.3 \mathrm{E} 2 \\
\approx 1 \\
7.1 \mathrm{E} 1 \\
3.9 \mathrm{E} 3\end{array}$ & $\begin{array}{c}\approx 1 \\
\approx 1 \\
\approx 1 \\
1.9 \mathrm{E} 3\end{array}$ & $\begin{array}{l}2.3 \mathrm{E} 2 \\
2.1 \mathrm{E} 2 \\
1.6 \mathrm{E} 2 \\
1.1 \mathrm{E} 3\end{array}$ \\
\hline $\begin{array}{l}5.0 \mathrm{E}-6 \\
1.0 \mathrm{E}-5\end{array}$ & $\begin{array}{l}2.9 \mathrm{E} 4 \\
3.3 \mathrm{E} 4\end{array}$ & $\begin{array}{c}\approx 1 \\
4.9 \mathrm{E} 4\end{array}$ & $\underset{5.6 \mathrm{E} 4}{\approx 1}$ & $\begin{array}{l}2.2 \mathrm{E} 4 \\
1.7 \mathrm{E} 4\end{array}$ & $\begin{array}{l}3.7 \mathrm{E} 4 \\
3.2 \mathrm{E} 4\end{array}$ & $\begin{array}{l}6.6 \mathrm{E} 4 \\
5.8 \mathrm{E} 4\end{array}$ \\
\hline
\end{tabular}

The 6-d samples are averages of three determinations: (a) centrifuged once; (b) centrifuged twice; and (c) centrifuged and then filtered. All other samples were centrifuged once.

${ }^{b}$ Read as $2.5 \times 10^{-7}$.

'In these cases, $K_{d}$ was larger in the samples clarified by method (c), indicating the presence of small particles not completely removed by centrifugation. 
Cesium concentrations of $5 \times 10^{-6}$ and $1 \times 10^{-5} \underline{\mathrm{M}}$ yield cesium loadings in the $10 \mathrm{ppm}$ sorbent of about 0.25 and $0.5 \mathrm{meq} / \mathrm{g}$, respectively, when about half the total cesium is loaded, as was the case here. These results show that sorbent concentrations greater than $10 \mathrm{ppm}$ are necessary for effective cesium removal from W-29 simulant at $\mathrm{pH} 10$ and suggest that conversion of the sorbent to the cesium form (CsNiFC or CsCoFC), by exchanging cesium for the other alkali metals, stabilizes the ferrocyanides against decomposition.

A different set of experiments with slurries containing 10,20 , or $40 \mathrm{ppm} \mathrm{NaNiFC}$ and cesium carrier indicated that cesium removal is inhibited at $\mathrm{pH} 10$, compared with $\mathrm{pH} 7$ (Table 3). The effect of cesium concentration at $\mathrm{pH} 7$ with $10 \mathrm{ppm}$ sorbent appeared to be modest, with a small decrease in cesium removal as the concentration increased. The cesium loading of the sorbent was surprisingly large in the case of $5 \times 10^{-5} \underline{\mathrm{M}}$ cesium, corresponding to $2.6 \mathrm{meq} / \mathrm{g}$ sorbent. At $\mathrm{pH} 10$ with $10 \mathrm{ppm}$ sorbent, cesium removal was about the same at $2.5 \times 10^{-6}$ to $5 \times 10^{-5} \underline{\mathrm{M}}$ at $1 \mathrm{~h}$ and $1 \mathrm{~d}$ but decreased after $4 \mathrm{~d}$. Only in the case of $5 \times 10^{-5} \mathrm{M}$ cesium did cesium removal become very small. This is in contrast to the observation reported in Table 2 , in which increased cesium concentration (to a maximum of $1 \times 10^{-5} \underline{\mathrm{M}}$ ) caused an improvement in cesium removal; however, at $5 \times 10^{-5}$ $\underline{\mathbf{M}}$, more cesium is present than can be exchanged into the sorbent. Although an accurate cesium concentration has not been reported for the waste, earlier results indicate that cesium is $<0.5 \mathrm{ppm}$, or $<4 \times 10^{-6} \underline{\mathrm{M}}$, well within the range of these measurements. Therefore, the data indicate that the cesium loading from the MVST waste will not significantly reduce the efficiency of cesium removal.

At $\mathrm{pH} \mathrm{7,} \mathrm{cesium} \mathrm{removal} \mathrm{always} \mathrm{increased} \mathrm{with} \mathrm{time;} \mathrm{at} \mathrm{pH} 10$, however, it decreased

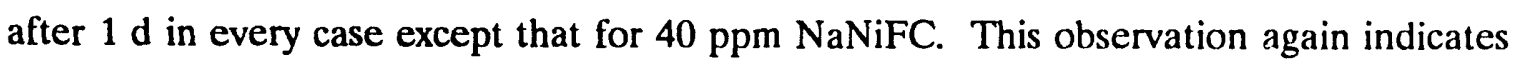
that the ferrocyanides lose effectiveness as $\mathrm{pH}$ increases, probably as the result of decomposition (metathesis) of the sorbent to form the transition-metal hydroxide $\left[\mathrm{Ni}(\mathrm{OH})_{2}\right]$ as $\mathrm{pH}$ increases. As the sorbent dosage increases, this effect becomes less important. Thus, at $\mathrm{pH} 10$ with low cesium concentrations, $10 \mathrm{ppm}$ sorbent is relatively ineffective; however,

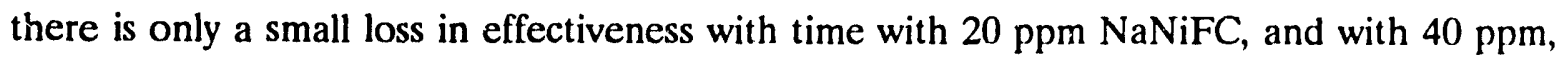
the cesium removal increased over the test period. Other data have shown that effectiveness is lost at $\mathrm{pH}$ about 11 when $100 \mathrm{ppm}$ sorbent is used. 
Table 3. Effects of cesium concentration, $\mathrm{pH}$, and $\mathrm{NaNiFC}$ concentration on cesium removal

\begin{tabular}{|c|c|c|c|c|c|}
\hline \multirow[b]{2}{*}{ Cs $(\underline{\mathrm{M}})$} & \multirow{2}{*}{$\begin{array}{c}\text { NaNiFC } \\
\text { conc. } \\
\text { (ppm) }\end{array}$} & \multirow[b]{2}{*}{$\mathrm{pH}$} & \multicolumn{3}{|c|}{$\mathrm{K}_{\mathrm{d}}$ after: } \\
\hline & & & $1 \mathrm{~h}$ & $1 \mathrm{~d}$ & $4 d^{a}$ \\
\hline $2.5 \mathrm{E}-7$ & 10 & 7 & $1.0 \mathrm{E} 5$ & $1.9 \mathrm{E} 5$ & $3.6 \mathrm{E} 5$ \\
\hline $2.5 \mathrm{E}-6$ & 10 & 7 & $7.3 \mathrm{E} 4$ & $1.4 \mathrm{E} 5$ & $3.2 \mathrm{E} 5$ \\
\hline $5.0 \mathrm{E}-6$ & 10 & 7 & $5.6 \mathrm{E} 4$ & $1.0 \mathrm{E} 5$ & -- \\
\hline $5.0 \mathrm{E}-5$ & 10 & 7 & -- & -- & $6.7 \mathrm{E} 4$ \\
\hline $5.0 \mathrm{E}-6$ & 40 & 7 & $8.9 \mathrm{E} 4$ & $2.4 \mathrm{E} 5$ & -- \\
\hline $5.0 \mathrm{E}-5$ & 40 & 7 & -- & -- & $1.4 \mathrm{E} 5$ \\
\hline $2.5 \mathrm{E}-6$ & 10 & 10 & $4.8 \mathrm{E} 4$ & $4.6 \mathrm{E} 4$ & $1.0 \mathrm{E} 4$ \\
\hline $2.5 \mathrm{E}-6$ & 20 & 10 & $9.1 \mathrm{E} 4$ & $1.2 \mathrm{E} 5$ & $6.1 \mathrm{E} 4$ \\
\hline $2.5 \mathrm{E}-6$ & 40 & 10 & $1.8 \mathrm{E} 5$ & 4.1E5 & $9.3 \mathrm{E} 5$ \\
\hline $5.0 \mathrm{E}-6$ & 10 & 10 & $4.3 \mathrm{E} 4$ & $5.0 \mathrm{E} 4$ & $2.9 \mathrm{E} 4$ \\
\hline 5.0E-5 & 10 & 10 & $52 \mathrm{E} 4$ & 4.0E4 & $1.2 \mathrm{E} 3$ \\
\hline
\end{tabular}

Results of a comparison of $\mathrm{KCOFC}$ and $\mathrm{NaCoFC}$ slurries prepared according to the Savannah River method ${ }^{15}$ showed that each product had limited stability at $\mathrm{pH} 11.1$ (Table 4). In this test, different amounts of sorbent from 20 to $200 \mathrm{ppm}$ were used. At pH 9.2, the two materials were generally comparable except for the $20 \mathrm{ppm} \mathrm{NaCoFC}$ series, which gave lower results than the others. At $\mathrm{pH} \mathrm{11,} \mathrm{both} \mathrm{materials} \mathrm{were} \mathrm{ineffective} \mathrm{at} 20$ and $50 \mathrm{ppm}$, but $\mathrm{K}_{d}$ increased with higher sorbent concentrations, 100 and $200 \mathrm{ppm}$. At pH 11 with 100 and $200 \mathrm{ppm}$ sorbent, the $\mathrm{K}_{\mathrm{d}}$ decreased from 1 or $6 \mathrm{~h}$ to 3 or $4 \mathrm{~d}$. With 200 ppm sorbent at $\mathrm{pH} 11, \mathrm{NaCoFC}$ gave larger $\mathrm{K}_{d} s$ than did $\mathrm{KCoFC}$ at longer times; however, at still higher $\mathrm{pH}$ levels, both compositions became ineffective.

\subsubsection{Removal of Cesium from High-pH Solutions with Dried KCoFC}

Since the dried, granular KCoFC is resistant to decomposition by solutions of $\mathrm{pH}$ higher than 11 , a series of experiments was conducted at $\mathrm{pH} 9,12$, and 13 using amounts of 
Table 4. Distribution coefficients of KCoFC and NaCoFC at different sorbent loadings

\begin{tabular}{lcccc}
\hline \multirow{2}{*}{ Time } & \multicolumn{4}{c}{ Amount of sorbent $(\mathrm{ppm})$} \\
\cline { 2 - 5 } & 20 & 50 & 100 & 200 \\
\hline KCoFC, $\mathrm{pH} \mathrm{9.2}$ & & & & \\
$12 \mathrm{~min}$ & $3.1 \mathrm{E} 4$ & $6.9 \mathrm{E} 4$ & $4.5 \mathrm{E} 4$ & $1.1 \mathrm{E5}$ \\
$1 \mathrm{~h}$ & $6.8 \mathrm{E} 4$ & $1.5 \mathrm{E} 5$ & $1.5 \mathrm{E} 5$ & $1.8 \mathrm{E5}$ \\
$6 \mathrm{~h}$ & $2.3 \mathrm{E} 5$ & $3.3 \mathrm{E} 5$ & $3.4 \mathrm{E} 5$ & $3.6 \mathrm{E} 5$ \\
$3 \mathrm{~d}$ & $6.7 \mathrm{E} 5$ & $6.4 \mathrm{E} 5$ & $7.9 \mathrm{E} 5$ & $8.6 \mathrm{E} 5$ \\
$4 \mathrm{~d}$ & $5.5 \mathrm{E} 5$ & $5.0 \mathrm{E} 5$ & $3.0 \mathrm{E} 5$ & $2.4 \mathrm{E} 5$ \\
$4 \mathrm{~d}$, filt. & $8.4 \mathrm{E} 5$ & $1.1 \mathrm{E} 6$ & $1.9 \mathrm{E} 6$ & $2.8 \mathrm{E} 6$
\end{tabular}

$\underline{\mathrm{KCoFC}}, \mathrm{pH} 11.1$

$12 \mathrm{~min}$

$1 \mathrm{~h}$

$6 \mathrm{~h}$

$3 \mathrm{~d}$

$4 d$

NaCoFC, pH 9.2

$12 \mathrm{~min}$

$1 \mathrm{~h}$

$6 \mathrm{~h}$

$3 \mathrm{~d}$

$4 \mathrm{~d}$

4 d, filt.
4.4E2

$-0$

$\sim 0$

$\sim 0$

$--$

$1.3 \mathrm{E} 4$

$2.5 \mathrm{E} 4$

$6.6 \mathrm{E} 4$

$1.3 \mathrm{E} 5$

$1.4 \mathrm{E} 5$

$1.5 \mathrm{E} 5$
3.7E2

$\sim 0$

$\sim 0$

$\sim 0$

$-$

8.7E4

$1.8 \mathrm{E} 5$

3.8E5

8.1E5

7.4E5

1.2E6
$5.2 \mathrm{E} 3$

$5.4 \mathrm{E} 3$

3.7E3

$1.7 \mathrm{E} 3$

--

6.9E4

$1.9 \mathrm{E} 5$

4.6E5

$6.7 \mathrm{E} 5$

$6.2 \mathrm{E} 5$

2.2E6

$6.2 \mathrm{E} 3$

$1.5 \mathrm{E} 4$

$2.0 \mathrm{E} 4$

$5.6 \mathrm{E} 2$
2.5E5

4.9E5

4.1E5

$3.4 \mathrm{E} 4$

$1.9 \mathrm{E} 4$

$\mathrm{NaCoFC}, \mathrm{pH} 11.1$

\begin{tabular}{lllll}
\hline $12 \mathrm{~min}$ & 41 & $\sim 0$ & $6.2 \mathrm{E} 3$ & $2.3 \mathrm{E} 5$ \\
$1 \mathrm{~h}$ & $\sim 0$ & $\sim 0$ & $1.5 \mathrm{E} 4$ & $6.9 \mathrm{E} 5$ \\
$6 \mathrm{~h}$ & -0 & $\sim 0$ & $2.0 \mathrm{E} 4$ & $3.7 \mathrm{E} 5$ \\
$3 \mathrm{~d}$ & $\sim 0$ & $\sim 0$ & $5.6 \mathrm{E} 2$ & $2.1 \mathrm{E} 5$ \\
$4 \mathrm{~d}$ & -- & -- & -- & $3.1 \mathrm{E} 5$ \\
\hline
\end{tabular}


sorbent between 67 and $667 \mathrm{ppm}$. The KCoFC was prepared according to the Savannah River method, ${ }^{15}$ dried at $100^{\circ} \mathrm{C}$, and screened to $100-230$ mesh particle size. The results are reported in Table 5. At $\mathrm{pH} 9$, the fractional cesium removal increased steadily with time and the amount of KCoFC added. It is apparent that, although a substantial degree of cesium exchange was achieved within a few hours, the fraction removed continued to increase even after $3 \mathrm{~d}$.

At $\mathrm{pH} 12$, the cesium removal increased to a maximum in the time range of 1 to $3 \mathrm{~d}$ and then decreased somewhat at $14 \mathrm{~d}$. The exception to this is the test with the largest $\mathrm{KCOFC}$ addition, $667 \mathrm{ppm}$, in which cesium removal remained essentially constant from 1 to $14 \mathrm{~d}$. Thus, with a relatively large amount of sorbent, effective cesium removal was achieved for contact times of at least $14 \mathrm{~d}$ at $\mathrm{pH} 12$.

The performance was degraded considerably more at $\mathrm{pH} 13$ than at $\mathrm{pH} 12$. Cesium removal was decreasing within $1 \mathrm{~d}$, but it was still $>90 \%$ for $3 \mathrm{~d}$ in the case of the largest KCoFC addition. Thus, even at $\mathrm{pH} 13$, significant cesium removal can be realized over a period of the order of $1 \mathrm{~d}$ to perhaps a few days if the amount of sorbent is large enough. These results also indicate that the storage of cesium-loaded sorbents at high $\mathrm{pH}$ levels will result in decomposition of the sorbent and release of the sorbed cesium.

The large range of sorbent concentrations obscures the actual exchange properties, and the same data are presented as $K_{d}$ values in Table 6. Over the time interval up to $3 d, K_{d}$ values are generally larger at $\mathrm{pH} 12$ than at $\mathrm{pH} \mathrm{9,} \mathrm{although} \mathrm{they} \mathrm{subsequently} \mathrm{decrease} \mathrm{at}$ longer times at $\mathrm{pH} 12$. It can be seen that, in most cases, the $\mathrm{K}_{\mathrm{d}}$ value did not change significantly as the sorbent dosage increased by a factor of 10 , from $67 \mathrm{ppm}$ to $667 \mathrm{ppm}$. The major exceptions to this generalization are for the longest time of mixing at $\mathrm{pH} 12$ and 13, at which $\mathrm{K}_{d}$ increased for the largest amount of sorbent.

It is clear that, at lower $\mathrm{pH}$ levels, $\mathrm{K}_{d}$ is smaller with the granular form of $\mathrm{KCoFC}$ (compare the $\mathrm{pH} 9.1$ data in Table 6 with the $\mathrm{pH} 10$ data in Table 2), probably because of a smaller surface area. The advantage of the heat-treated, granular sorbent is its resistance to high-pH solutions. The loss of effectiveness with increasing time at high $\mathrm{pH}$ is probably caused by slow metathesis of part of the sorbent to $\mathrm{Co}(\mathrm{OH})_{2}$, which effectively reduces the amount of KCoFC. Such a reaction to decompose part of the sorbent is apparently much slower with the granular $\mathrm{KCoFC}$ than with slurries that become ineffective at $\mathrm{pH} 13$ within a much shorter time. Since decomposition of the sorbent is probably related to solubility products, excess sorbent can be added to compensate for the loss of effectiveness. 
Table 5. Percent removal of cesium at high $\mathrm{pH}$ with granular KCoFC

\begin{tabular}{|c|c|c|c|c|}
\hline \multirow[t]{2}{*}{ Time } & \multicolumn{4}{|c|}{ Granular KCoFC (ppm) } \\
\hline & 67 & 133 & 333 & 667 \\
\hline \multicolumn{5}{|c|}{ pH 9.1} \\
\hline $2 \mathrm{~h}$ & 47 & 60 & 83 & 94 \\
\hline $6 \mathrm{~h}$ & 63 & 74 & 90 & 96.5 \\
\hline $24 \mathrm{~h}$ & 77 & 85 & 94 & 98.1 \\
\hline $3 d$ & 83 & 89 & 95 & 98.5 \\
\hline $14 \mathrm{~d}$ & 89 & 92 & 97 & 99.0 \\
\hline \multicolumn{5}{|c|}{$\mathrm{pH} 12.1$} \\
\hline $2 \mathrm{~h}$ & 59 & 81 & 90 & 96.5 \\
\hline $6 \mathrm{~h}$ & 77 & 90 & 95 & 98.2 \\
\hline $24 \mathrm{~h}$ & 88 & 95 & 97 & 99.1 \\
\hline $3 d$ & 87 & 95 & 98 & 99.1 \\
\hline $14 \mathrm{~d}$ & 75 & 90 & 95 & 99.2 \\
\hline \multicolumn{5}{|c|}{$\mathrm{pH} 13.2$} \\
\hline $2 \mathrm{~h}$ & 74 & 83 & 90 & 96.9 \\
\hline $6 \mathrm{~h}$ & 78 & 86 & 91 & 97.1 \\
\hline $24 \mathrm{~h}$ & 73 & 82 & 89 & 96.6 \\
\hline $3 d$ & 42 & 58 & 73 & 91.3 \\
\hline $14 \mathrm{~d}$ & 0 & 0 & 3 & 57.4 \\
\hline
\end{tabular}

A commercial preparation of KCoFC that had been marketed by Bir-Rad some years ago, but is no longer available, was tested at $\mathrm{pH} 9,11,12$, and 13; the results are shown in Table 7. The distribution coefficients increased with time at $\mathrm{pH} 9$ but showed a maximum at some intermediate time at the higher pHs. The higher the $\mathrm{pH}$, the shorter the time to the maximum. As in the cases reported above, the values tended to be smaller at pIi 9 than at the higher pHs, except for the longer exposure times. After $4 \mathrm{~d}$, this material is slightly superior to the preparation described in the preceding tables. 
Table 6. Cesium distribution coefficients at high pH with granular KCoFC

\begin{tabular}{|c|c|c|c|c|}
\hline \multirow[t]{2}{*}{ Time } & \multicolumn{4}{|c|}{ Granular KCoFC (ppm) } \\
\hline & 67 & 133 & 333 & 667 \\
\hline \multicolumn{5}{|c|}{$\mathrm{pH} 9.1$} \\
\hline $2 \mathrm{~h}$ & $1.4 \mathrm{E} 4$ & $1.2 \mathrm{E} 4$ & $1.5 \mathrm{E} 4$ & $2.3 \mathrm{E} 4$ \\
\hline $6 \mathrm{~h}$ & $2.5 \mathrm{E} 4$ & $2.1 \mathrm{E} 4$ & $2.6 \mathrm{E} 4$ & 4.1E4 \\
\hline $24 \mathrm{~h}$ & $4.8 \mathrm{E} 4$ & $4.1 \mathrm{E} 4$ & 4.7E4 & $7.7 \mathrm{E} 4$ \\
\hline $3 d$ & $6.9 \mathrm{E} 4$ & $5.8 \mathrm{E} 4$ & $6.0 \mathrm{E} 4$ & $9.8 \mathrm{E} 4$ \\
\hline $14 \mathrm{~d}$ & $1.1 \mathrm{E} 5$ & 8.7E4 & $9.8 \mathrm{E} 4$ & $1.5 \mathrm{E} 5$ \\
\hline \multicolumn{5}{|c|}{$\mathrm{pH} 12.1$} \\
\hline $2 \mathrm{~h}$ & $2.1 \mathrm{E} 4$ & $3.2 \mathrm{E} 4$ & $2.3 \mathrm{E} 4$ & $4.3 \mathrm{E} 4$ \\
\hline $6 \mathrm{~h}$ & $5.0 \mathrm{E} 4$ & $7.0 \mathrm{E} 4$ & $5.2 \mathrm{E} 4$ & $8.2 \mathrm{E} 4$ \\
\hline $24 \mathrm{~h}$ & $1.1 \mathrm{E} 5$ & $1.4 \mathrm{E} 5$ & $1.1 \mathrm{E} 5$ & $1.7 \mathrm{E} 5$ \\
\hline $3 d$ & $1.0 \mathrm{E} 5$ & $1.4 \mathrm{E} 5$ & $1.2 \mathrm{E} 5$ & $1.7 \mathrm{E} 5$ \\
\hline $14 \mathrm{~d}$ & $4.6 \mathrm{E} 4$ & $6.5 \mathrm{E} 4$ & $6.0 \mathrm{E} 4$ & $1.9 \mathrm{E} 5$ \\
\hline \multicolumn{5}{|c|}{$\mathrm{pH} 13.2$} \\
\hline $2 \mathrm{~h}$ & 4.3E4 & $3.8 \mathrm{E} 4$ & $2.7 \mathrm{E} 4$ & $4.7 \mathrm{E} 4$ \\
\hline $6 \mathrm{~h}$ & $5.4 \mathrm{E} 4$ & $4.6 \mathrm{E} 4$ & $3.1 \mathrm{E} 4$ & $5.0 \mathrm{E} 4$ \\
\hline $24 \mathrm{~h}$ & $4.1 \mathrm{E} 4$ & $3.5 \mathrm{E} 4$ & $2.4 \mathrm{E} 4$ & $4.2 \mathrm{E} 4$ \\
\hline $3 d$ & $1.3 \mathrm{E} 4$ & $1.1 \mathrm{E} 4$ & $8.5 \mathrm{E} 3$ & $1.6 \mathrm{E} 4$ \\
\hline $14 \mathrm{~d}$ & $5.2 \mathrm{E} 2$ & 7.7E2 & 7.7E2 & $2.4 \mathrm{E} 3$ \\
\hline
\end{tabular}

Table 7. Cesium distribution coefficients at high $\mathrm{pH}$ with commercial KCoFC

\begin{tabular}{ccccc}
\hline & \multicolumn{4}{c}{$\mathrm{pH}$} \\
\cline { 2 - 5 } Time & 9 & 11 & 12 & 13 \\
\hline $1 \mathrm{~h}$ & $1.2 \mathrm{E} 3$ & $1.6 \mathrm{E} 3$ & $2.4 \mathrm{E} 3$ & $6.3 \mathrm{E} 3$ \\
$24 \mathrm{~h}$ & $2.7 \mathrm{E} 4$ & $5.7 \mathrm{E} 4$ & $5.3 \mathrm{E} 4$ & $4.1 \mathrm{E} 4$ \\
$4 \mathrm{~d}$ & $7.6 \mathrm{E} 4$ & $1.3 \mathrm{E} 5$ & $1.0 \mathrm{E} 5$ & $1.7 \mathrm{E} 4$ \\
$7 \mathrm{~d}$ & $1.0 \mathrm{E} 5$ & $1.7 \mathrm{E} 5$ & $9.8 \mathrm{E} 4$ & $8.0 \mathrm{E} 3$ \\
$14 \mathrm{~d}$ & $1.4 \mathrm{E} 5$ & $9.1 \mathrm{E} 4$ & $8.5 \mathrm{E} 4$ & $2.5 \mathrm{E} 3$ \\
\hline \multicolumn{2}{l}{333 ppm of 20-50 mesh particles supplied by Bio-Rad. }
\end{tabular}




\subsubsection{Removal of Cesium with Other Transition-Metal Ferrocyanides}

Scouting tests were carried out with copper, ferric iron, ferrous iron, manganese, and zinc ferrocyanides. Copper ferrocyanide (KCuFC) is available in limited quantities in France and has been studied in England. The material used in the tests was prepared according to the Savannah River method for KCoFC. ${ }^{15}$ The solid was dried at $75^{\circ} \mathrm{C}$, crushed, and screened; a 100-200 mesh size fraction was used at a dosage of $333 \mathrm{ppm}$. The results (Table 8) show that this sorbent is comparable, or perhaps somewhat superior, to KCoFC at $\mathrm{pH} 9$ (see Table 6) but loses its effectiveness at $\mathrm{pH} 11$ or greater much more rapidly than does KCoFC. In an identical experiment, carried out for comparison, NaNiFC slurry was used at $100 \mathrm{ppm}$ (Table 8). The results show that granular $\mathrm{KCuFC}$ is useful at $\mathrm{pH}<11$ but is not as effective as nickel or cobalt ferrocyanide slurries; at higher pHs, it is not as effective as granular $\mathrm{KCoFC}$.

Several preparations of the zinc compound were tested, both as a slurry and as a dried solid prepared with a range of stoichiometric ratios. All forms were relatively ineffective with the W-29 simulant solution, yielding $\mathrm{K}_{d}$ values generally less than 1000 (10\% cesium removal with $100 \mathrm{ppm}$ sorbent). Since the material had been reported to be useful, some further tests were carried out. With normal tap water at $\mathrm{pH} \mathrm{6.8,} \mathrm{zinc} \mathrm{ferrocyanide} \mathrm{gave} \mathrm{K}_{\mathrm{d}}$ values of about $2 \times 10^{5}$; with $1 \underline{\mathrm{M}} \mathrm{NaNO}_{3}$ at $\mathrm{pH} 8.6$, the $\mathrm{K}_{\mathrm{d}}$ was about $1 \times 10^{4}$. It is concluded that, although this sorbent is reasonably effective in water or low-salt concentrations, it is not nearly as selective for cesium over sodium in high-salt solutions as are some of the other sorbents. Therefore, it was not studied further.

One set of tests was performed with manganous ferrocyanide slurry prepared in the same way as $\mathrm{NaNiFC}$, using tap watcr and $3 \underline{\mathrm{M}} \mathrm{NaNO}_{3}$ at $\mathrm{pH} 7$ to 8 . With tap water, it was quite effective over short times (hours), with $K_{d}=1.5 \times 10^{6}$; however, the $K_{d}$ decreased with time and was only $5.6 \times 10^{4}$ after $14 \mathrm{~d}$. With the $3 \underline{\mathrm{M} \mathrm{NaNO}}$ it was relatively inefiective at all times, decreasing from $1.5 \times 10^{4}$ after 12 min to $1.2 \times 10^{2}$ after $14 \mathrm{~d}$. This material is an inferior sorbent for cesium from high salt solutions, and it was not investigated further.

One set of tests was made with potassium ferric ferrocyanide (Prussian blue) prepared by a slow crystal growth method. This compound normally has very small particles or is colloidal, but the slow crystai growth method yielded solids that could be handled. This sorbent was reasonably effective in tap water, giving $\mathrm{K}_{\mathrm{d}}$ values of nearly $1 \times 10^{6}$ and $2 \times 10^{5}$ at $\mathrm{pH} 8$ and 10, respectively. However, it was inferior to other sorbents in the W-29 
Table 8. Cesium distribution coefficients with granular KCuFC (100-200 mesh, 333 ppm) and NaNiFC slurry

\begin{tabular}{|c|c|c|c|c|c|c|}
\hline \multirow[t]{2}{*}{ Time } & \multicolumn{3}{|c|}{$\begin{array}{c}\text { Granular KCuFC } \\
\text { at pH of }\end{array}$} & \multicolumn{3}{|c|}{$\begin{array}{c}\text { NaNiFC Slurry at } \\
\text { pH of: }\end{array}$} \\
\hline & 9 & 11 & 12 & 9 & 11 & 12 \\
\hline $\begin{array}{r}1 \mathrm{~h} \\
24 \mathrm{~h}\end{array}$ & $\begin{array}{l}3.2 \mathrm{E} 4 \\
2.4 \mathrm{E} 5\end{array}$ & $\begin{array}{l}4.0 \mathrm{E} 3 \\
8.9 \mathrm{E} 1\end{array}$ & $\sim_{92}^{0}$ & $\begin{array}{l}8.6 \mathrm{E} 4 \\
7.4 \mathrm{E} 5\end{array}$ & $\begin{array}{l}4.1 \mathrm{E} 4 \\
3.8 \mathrm{E} 5\end{array}$ & $\begin{array}{l}2.7 \mathrm{E} 4 \\
5.9 \mathrm{E} 3\end{array}$ \\
\hline $4 d$ & $3.8 \mathrm{E} 5$ & $2.4 \mathrm{E} 1$ & 5 & $2.2 \mathrm{E} \sigma$ & 7.1E5 & 5.9E1 \\
\hline $\begin{array}{r}7 d \\
14 d \\
\end{array}$ & $\begin{array}{l}3.7 \mathrm{E} 5 \\
3.9 \mathrm{E} 5 \\
\end{array}$ & $\begin{array}{l}2.2 \mathrm{E} 1 \\
2.5 \mathrm{E} 1 \\
\end{array}$ & $\begin{array}{r}9 \\
23 \\
\end{array}$ & $\begin{array}{l}1.5 \mathrm{E} 6 \\
1.6 \mathrm{E} 6 \\
\end{array}$ & $\begin{array}{l}6.0 \mathrm{E} 5 \\
1.1 \mathrm{E} 5 \\
\end{array}$ & $\begin{array}{l}\sim 0 \\
\sim 0 \\
\end{array}$ \\
\hline
\end{tabular}

simulant, giving $\mathrm{K}_{\mathrm{d}}$ values of $2 \times 10^{4}$ and $\sim 0$ at $\mathrm{pH} 7$ and 11 , respectively. It was not studied further.

An experiment was made with potassium ferrous ferrocyanide prepared by drying the precipitate at $75^{\circ} \mathrm{C}$, crushing, and screening the product; the 100-200 mesh size fraction was used. The material was generally less satisfactory than other sorbents for cesium removal from W-29 simulant, giving $K_{d} s$ in the range of $3 \times 10^{3}$ to $5 \times 10^{3}$ at $\mathrm{pH} 9$ and $<1 \times 10^{3}$ at $\mathrm{pH}$ 11. It was not studied further.

\subsubsection{Removal of Cesium from Acid Solutions with Ferrocyanides}

Scouting experiments were carried out to test the ability of ferrocyanides to remove cesium from acid solutions. A process utilizing such compounds would be useful for decontaminating acidic waste solutions at the source. The base solutions were acidified W-29 simulant solution (high salt concentration) and water. Each was adjusted by adding a quantity of $\mathrm{HCl}$ calculated to increase the acid concentrations to $1,0.1$, and $0.01 \underline{\mathrm{M}}$. This adjustment was reasonably successful in the case of water as the final $\mathrm{pHs}$ were 0,1 , and 2.3 (these solutions would be representative of a condensate from an acid evaporator, for example); however, the W-29 simulant was more alkaline than expected, and the final pHs were $0,7.6$, and 7.9. The only useful new data from the salt solutions are those for $1 \underline{\mathrm{M}}$ acid in high-salt concentration, which is a nontypical composition for a waste solution. 
The results (Table 9) show that, while 100-ppm quantities of both KCoFC and NaNiFC slurries are reasonably effective with the acidic water solutions, NaNiFC is superior. Decreasing the pH below 2 has a deleterious effect, but cesium removal is about as complete at $\mathrm{pH} 2.3$ as it is at high $\mathrm{pH}$ levels. Thus, the ferrocyanides are equally useful in water over the $\mathrm{pH}$ range from 11 to 2 , with a small decrease in effectiveness as the $\mathrm{pH}$ deireases to 0 . With the acidified W-29 simulant, NaNiFC is clearly superior to KCoFC, with about $90 \%$ cesium removal (DF of 10 ) being attained with $100 \mathrm{ppm}$ of sorbent. It is clear that cesium can be removed from acidified salt solutions, even up to $1 \underline{M}$ acid, but cesium removal is more effective at higher $\mathrm{pH}$ levels.

Additional experiments were conducted to test the effectiveness of NaNiFC slurries at higher acidities (Table 10). With $1 \underline{\mathrm{M}}$ acid, cesium decontamination was somewhat less effective than that reported in Table 9. However, reasonably good cesium removal was obtained from both $1 \underline{\mathrm{M}}$ and $2 \underline{\mathrm{M}} \mathrm{HNO}_{3}$, with about $90 \%$ of the cesium being removed with $100 \mathrm{ppm}$ sorbent. The use of NaNiFC for cesium decontamination of acid solutions, such as evaporator condensates and decontamination solutions, is suggested if it is not practical to increase the $\mathrm{pH}$ of the solution to improve the effectiveness of the sorbent.

\subsection{Removal of Cesium from MVST Supernate Solutions with Inorganic Sorbents}

Results of one experiment conducted with supernate solution from MVST W-29 were reported previously. ${ }^{2}$ Only a single stage of separation was used in that test. Since a larger DF is required to meet specifications for some waste forms, particularly discharges to the environment, another experiment was conducted to determine whether the decontamination effectiveness continued through multiple stages. It is not uncommon for a large DF to be achieved in the first treatment, leaving a small fraction of the activity that is much more difficult to remove, presumably because it is a different chemical species.

An experiment was conducted to test a batch processing flowsheet using three successive stages. Such flowsheets are described in a separate report in preparation. The experiment was conducted with $1 \mathrm{~L}$ of supernate from MVST W-26. This solution was obtained from an earlier sample taken prior to some recent solution transfers between the MVST tanks so there are no detailed composition data. The experimental results are summarized in Table 11. 
Table 9. Cesium distribution coefficients for acidified solutions with 100 ppm ferrocyanides

\begin{tabular}{|c|c|c|c|c|c|c|}
\hline \multirow{2}{*}{ Solution } & \multirow[b]{2}{*}{$\mathrm{pH}$} & \multirow[b]{2}{*}{ Sorbent } & \multicolumn{4}{|c|}{ Time } \\
\hline & & & $1 \mathrm{~h}$ & $1 \mathrm{~d}$ & $14 \mathrm{~d}$ & $14 \mathrm{~d}^{\mathrm{b}}$ \\
\hline Water & 0 & $\mathrm{KCoFC}$ & $2.0 \mathrm{E} 5$ & 2.3E5 & $2.4 \mathrm{E} 5$ & $5.2 \mathrm{E} 5$ \\
\hline Water & 1.0 & $\mathrm{KCoFC}$ & $5.6 \mathrm{E} 5$ & $5.1 \mathrm{E} 5$ & $6.1 \mathrm{E} 5$ & $1.4 \mathrm{E} 6$ \\
\hline Water & 2.3 & $\mathrm{KCoFC}$ & 3.3E6 & $1.4 \mathrm{E} 6$ & $1.1 \mathrm{E} 6$ & $3.8 \mathrm{E} 6$ \\
\hline Water & 0 & NaNiFC & 4.1E5 & $6.3 \mathrm{E} 5$ & $1.1 \mathrm{E} 6$ & 4.7E6 \\
\hline Water & 1.0 & NaNiFC & $3.3 \mathrm{E} 5$ & 7.7E5 & $1.5 \mathrm{E} 6$ & $3.4 \mathrm{E} 6$ \\
\hline Water & 2.3 & NaNiFC & 2.7E6 & $6.8 \mathrm{E} 5$ & $1.3 \mathrm{E} 6$ & $2.7 \mathrm{E} 6$ \\
\hline $\operatorname{Sim}^{c}$ & 0 & $\mathrm{KCoFC}$ & $6.7 \mathrm{E} 3$ & $5.7 \mathrm{E} 3$ & $4.8 \mathrm{E} 3$ & $5.5 \mathrm{E} 3$ \\
\hline Sim & 7.6 & KCoFC & $2.9 \mathrm{E} 5$ & $4.0 \mathrm{E} 5$ & $4.0 \mathrm{E} 5$ & $2.2 \mathrm{E} 6$ \\
\hline Sim & 7.9 & $\mathrm{KCoFC}$ & $5.6 \mathrm{E} 5$ & $1.3 \mathrm{E} 6$ & $1.9 \mathrm{E} 6$ & $1.7 \mathrm{E} 7$ \\
\hline Sim & 0 & NaNiFC & $7.5 \mathrm{E} 3$ & $3.6 \mathrm{E} 4$ & $1.4 \mathrm{E} 5$ & $1.6 \mathrm{E} 5$ \\
\hline Sim & 7.6 & NaNiFC & $2.4 \mathrm{E} 5$ & $4.9 \mathrm{E} 5$ & $1.5 \mathrm{E} 6$ & $3.3 \mathrm{E} 6$ \\
\hline$\underline{\text { Sim }}$ & 7.9 & NaNiFC & $3.1 \mathrm{E} 5$ & $9.4 \mathrm{E} 5$ & $9.0 \mathrm{E} 5$ & $8.3 \mathrm{E} 5$ \\
\hline
\end{tabular}

In the first separation stage, $1 \mathrm{~L}$ of the solution was adjusted to $\mathrm{pH} \sim 10.5$, NaNiFC slurry was added to $104 \mathrm{ppm}$, and NaT was added to $200 \mathrm{ppm}$. The slurry was mixed for $4 \mathrm{~h}$ and allowed to settle for $20 \mathrm{~h}$. Most of the supernate, which appeared to be clear, was decanted from the solids by vacium transfer. At this point, the DF was -18 . Centrifugation and filtration $(0.2-\mu \mathrm{m}$ pore size) gave DFs of 104 and 108 . Settling for longer times gave DFs that increased from $\sim 18$ to 32 after $36 \mathrm{~h}$ and 113 after $68 \mathrm{~h}$. In all cases, DFs in the range 104 to 114 were attained with good clarification (filtration, centrifugation, or settling for a few days); therefore, the supernate decanted after settling 20 h contained about $1 \%$ of the cesium in solution and about $4.5 \%$ of the cesium associated with suspended solids.

A $250-\mathrm{mL}$ portion of this supernate (sample A2, DF -18) was then treated with 104 ppm NaNiFC (second contact), and the DF in the second stage increased from 110 after $9 \mathrm{~min}$ to 234 after $1 \mathrm{~h}$ and 490 after $20 \mathrm{~h}$. The combined DF (both stages) was 2000 after 
Table 10. Cum removal from acid solutions with $100 \mathrm{ppm}$ NaNiFC at 4d contact time

\begin{tabular}{|c|c|c|c|c|}
\hline Sriution & $\begin{array}{l}\mathrm{HNO}_{3} \\
(\mathrm{M})\end{array}$ & Sample & $\%$ Removed & $\underline{K}_{d}$ \\
\hline \multirow[t]{3}{*}{ Water } & 1.0 & cent & 87.7 & $4.3 \mathrm{E} 4$ \\
\hline & & cent/cent & 88.1 & $4.5 \mathrm{E} 4$ \\
\hline & & cent/filt & 883.5 & 4.66E4 \\
\hline \multirow[t]{3}{*}{ Water } & 2.0 & cent & 87.7 & $4.3 \mathrm{E} 4$ \\
\hline & & cent/cent & 89.8 & $5.4 \mathrm{E} 4$ \\
\hline & & cent/filt & 90.7 & $5.9 \mathrm{E} 4$ \\
\hline \multirow[t]{3}{*}{ Simulant } & 1.0 & cent & 83.1 & $3.0 \mathrm{E} 4$ \\
\hline & & cent/cent & 83.8 & $3.1 \mathrm{E} 4$ \\
\hline & & cent/filt & 83.4 & $3.1 \mathrm{E} 4$ \\
\hline \multirow[t]{2}{*}{ Simulant } & 2.0 & cent & 77.3 & $2.1 \mathrm{E} 4$ \\
\hline & & cent/cent & 78.2 & $2.2 \mathrm{E} 4$ \\
\hline \multirow[t]{3}{*}{ Sirnulant } & 4.0 & cent & 63.0 & $1.03 \mathrm{E}^{2} r_{r}$ \\
\hline & & cent/cent & 64.4 & $1.1 \mathrm{E} 4$ \\
\hline & & cent/filt & 64.9 & $1.1 \mathrm{E} 4$ \\
\hline
\end{tabular}

$9 \mathrm{~min}$ and 9000 after $1 \mathrm{~d}$ (filtered samples). A third separation stage reduced the cesium activity to the limit of detection with the counting system available, with an overall DF of $>1.9 \times 10^{5}$ for the three cycles of decontamination.

This experiment confirms that cesium is present in exchangeable forms so that each of the successive stages of separation yields about the same DF, at least until nearly all the cesium has been removed. Such results clearly demonstrate that cesium can be reduced to a very low level, in the vicinity of permissible discharge limits. The primary uncertainty in extrapolating from this scale to a process level lies in the extended time (severai days) that took place between the first and second batch contacts. Sench-scale testing on a more realistic schedule will be required to verify the process applicability. Similar data were not obtained for ${ }^{90} \mathrm{Sr}$ because of budget limitations. 
Table 11. Test of three-stage batch separation of ${ }^{137} \mathrm{Cs}$ from W-26 supernate

\begin{tabular}{lllll}
\hline Solution & $\begin{array}{l}{ }^{137} \mathrm{Cs} \\
(\mathrm{Bg} / \mathrm{mL})\end{array}$ & $\begin{array}{l}\text { Cs DF } \\
\text { cycle }\end{array}$ & $\begin{array}{l}\text { Total } \\
\mathrm{DF}^{\mathbf{a}}\end{array}$ & Notes \\
\hline Feed & $1.89 \mathrm{E} 5$ & --- & &
\end{tabular}

First Extraction: Add 104 ppm NaNiFC + 200 ppm NaT; mix 4 h; let settle.

\begin{tabular}{|c|c|c|c|c|}
\hline $\begin{array}{l}\text { A1 } \\
\text { A2 }\end{array}$ & $\begin{array}{l}1.10 \mathrm{E} 4 \\
1.03 \mathrm{E} 4\end{array}$ & $\begin{array}{l}17 \\
18\end{array}$ & - & First $250 \mathrm{~mL}$ decanted after $20 \mathrm{~h}$ \\
\hline & $1.0 J E 7$ & & & Second $250 \mathrm{~mL}$ decanted after $20 \mathrm{~h}$ \\
\hline B2 & $5.85 \mathrm{E} 3$ & 32 & - & A2 after settling additional $16 \mathrm{~h}$ \\
\hline $\mathrm{C} 2$ & $1.81 \mathrm{E} 3$ & 104 & - & Same as B2 plus centrifuged \\
\hline F2 & $1.75 \mathrm{E} 3$ & 108 & - & Same as B2 plus filtered \\
\hline B3 & $1.68 \mathrm{E} 3$ & 113 & - & A2 after settling additional $2 \mathrm{~d}$ \\
\hline B4 & $1.66 \mathrm{E} 3$ & 114 & - & Duplicate of B3 \\
\hline
\end{tabular}

Second Extraction: Add 104 ppm NaNiFC + 200 ppm NaT to A2; mix.

$\begin{array}{lllll}2 \mathrm{~F} 1 & 94 & 110 & 2010 & \text { Filtered sample after mixing } 9 \mathrm{~min} \\ 2 \mathrm{~F} 2 & 76 & 135 & 2490 & \text { Filtered sample after mixing } 14 \mathrm{~min} \\ \text { 2F3 } & 58 & 178 & 3260 & \text { Filtered sample after mixing } 30 \mathrm{~min} \\ 2 \mathrm{~F} 4 & 44 & 234 & 4300 & \text { Filtered sample after mixing } 60 \mathrm{~min} \\ 2 \mathrm{~F} 5 & 21 & 490 & 9000 & \text { Filtered sample after } 20 \mathrm{~h}\end{array}$

Third Extrac n: Add 104 ppm NaNiFC to 2F5; mix.

\begin{tabular}{lllll}
$3 F 1$ & 0 & - & - & Filtered sample after mixing 2 min \\
$3 F 2$ & 3 & - & - & Filtered sample after mixing 8 min \\
$3 F 3$ & 0 & - & - & Filtered sample after mixing 30 min \\
$3 F 4$ & 1 & - & - & Filtered sample after mixing $60 \mathrm{~min}$ \\
Average & 1 & 21 & $1.9 \mathrm{E} 5$ & \\
\hline
\end{tabular}

"DF includes dilution factor of about 1.03 each cycle. 


\subsubsection{Removal of Strontium from Simulant Solutions with Inorganic Sorbents}

Several inorganic sorbents have been examined in screening tests with the W-29 simulant solution containing ${ }^{85} \mathrm{Sr}$ tracer and a small amount of actual W-29 supernate for a ${ }^{137} \mathrm{Cs}$ spike. The data are summarized in Table 12 . All materials removed strontium much more effectively at $\mathrm{pH} 13$ than at lower $\mathrm{pH}$ levels, and all but the Sandia sodium titanatc ${ }^{18}$ $(\mathrm{NaT})$ and titanium phosphate were relatively ineffective at $\mathrm{pH}<11$, which is the upper limit for long-term stability of ferrocyanides that might be used for cesium removal. At the higher pHs, NaT is clearly superior to all other materials tested. In a batch contact, 454 ppm removed $99 \%$ of the strontium at $\mathrm{pH} 13$ and about $90 \%$ at $\mathrm{pH} 11$, values that are in the range of practical application. This preparation had been formed into pellets and then ground to produce a granular product; it is anticipated that the original NaT, which was not heat-treated to form pellets, will have a larger $K_{d}$, and some of this material has recently been acquired for further testing.

A number of gel-derived microsphere preparations made by an internal gelation process were supplied by J. L. Collins, of ORNL. At lower pHs (10 and below), the titanium phosphate preparations were nearly as effective as $\mathrm{NaT}$, although they were inferior at high $\mathrm{pH}$ levels. Some of the gel-derived microsphere preparations were much better materials to work with because of the absence of fine powders, although some preparations tended to degrade during mixing. All showed much slower rates of sorption, as would be expected because of the small surface area. The data in Table 12 are for $24-\mathrm{h}$

mixing time; $\mathrm{K}_{d} \mathrm{~s}$ were observed to increase significantly over longer time intervals, up to $>15 \mathrm{~d}$ in some cases. Such long times are not practical for most process applications. At a $\mathrm{pH}$ of 10 or less, the TiP exchangers are comparable to NaT, and it is likely that an improved form could be synthesized. Accordingly, these results are sufficiently promising that additional work would be worthwhile to attempt to prepare microspheres with better exchange characteristics by varying the porosity and crystallinity.

None of these sorbents showed any significant removal of cesium under any conditions. 
Table 12. Strontium removal from W-29 simulant with inorganic sorbents

\begin{tabular}{|c|c|c|c|c|c|c|c|}
\hline \multirow{2}{*}{$\begin{array}{l}\text { Sorbent } \\
\text { type }\end{array}$} & \multirow{2}{*}{$\begin{array}{r}\text { Sorbent } \\
(\mathrm{ppm})\end{array}$} & \multicolumn{2}{|c|}{$\mathrm{pH} 10$} & $\mathrm{pH} 11$ & $\mathrm{pH} 12$ & \multicolumn{2}{|c|}{$\mathrm{pH} 13$} \\
\hline & & $\overline{K_{d}^{b}}$ & $\%^{c}$ & $\mathrm{~K}_{\mathrm{d}}^{\mathrm{b}} \%^{\mathrm{c}}$ & $\overline{\mathrm{K}_{\mathrm{d}}^{\mathrm{b}} \%^{\mathrm{c}}}$ & $\overline{K_{d}^{b}}$ & $\%^{\mathrm{c}}$ \\
\hline$\overline{\mathrm{NaT}}$ & 454 & $7.6 \mathrm{E} 3$ & 78 & $2.1 \mathrm{E} 4 \quad 91$ & $3.7 \mathrm{E} 4 \quad 94$ & $1.9 \mathrm{E} 5$ & 99 \\
\hline $\mathrm{TiO}_{2}$ & 1820 & $6.0 \mathrm{E} 1$ & 10 & $1.1 \mathrm{E} 2 \quad 17$ & $6.4 \mathrm{E} 2$ & $2.9 \mathrm{E} 3$ & 84 \\
\hline $\mathrm{SG}-\mathrm{TiO}_{2}$ & $\sim 300$ & & & $1.1 \mathrm{E} 3$ & & $1.5 \mathrm{E} 3$ & 37 \\
\hline SG-NaT-B & -300 & & & $1.8 \mathrm{E} 3$ & & $2.1 \mathrm{E} 3$ & 44 \\
\hline $\begin{array}{l}\text { SG-NaT-C } \\
\text { SG-ZrP }\end{array}$ & $\begin{array}{l}\sim 300 \\
-300\end{array}$ & $13 F ?$ & & 1.7E3 & & $\begin{array}{l}2.1 \mathrm{E} 3 \\
17 \mathrm{~F} 4\end{array}$ & $\begin{array}{l}45 \\
85\end{array}$ \\
\hline SG-TiP-A & $\sim 300$ & $4.1 \mathrm{E} 3$ & $\begin{array}{c}4 \\
58\end{array}$ & & & $\begin{array}{l}1.7 \mathrm{~L} 4 \\
2.2 \mathrm{E} 4\end{array}$ & 88 \\
\hline SG-TiP-B & -300 & $5.5 \mathrm{E} 3$ & 65 & & & $1.9 \mathrm{E} 4$ & 86 \\
\hline
\end{tabular}

${ }^{2} \mathrm{NaT}$ is granular sodium titanate made from the Sandia preparation; $\mathrm{TiO}_{2}$ is reagent-grade titania (Fisher); SG codes are gel-derived microsphere preparations made by the internal gelation process of the following: $\mathrm{TiO}_{2}$ is hydrous titanium oxide; NaT-B and NaT-C are hydrous titanium oxides treated with $\mathrm{NaOH}$; $\mathrm{ZrP}$ is hydrous zirconium oxide treated with phosphoric acid; and TiP-A and TiP-B are hydrous titanium oxide treated with phosphoric acid.

Values after $24 \mathrm{~h}$ of mixing; $\mathrm{K}_{\mathrm{d}}$ increased with longer times.

${ }^{c_{\%}}$ refers to the percentage of ${ }^{85} \mathrm{Sr}$ activity removed from solution after $24 \mathrm{~h}$.

\subsection{SIMULANT DECONTAMINATION WITH ORGANIC ION-EXCHANGE RESINS}

Organic ion-exchange resins have been used for removing various radioactive contaminants from low- and high-level radioactive liquid waste streams in the nuclear power industry for many years; they are especially effective in column configurations for the removal of trace amounts of specific constituents. In this study, organic ion-exchange resins, including a resorcinol-based resin developed and provided by the Savannah River Site $^{12}$ (designated SRS resin) and Duolite CS-100 phenol-based resin, were tested for their ability to remove ${ }^{137} \mathrm{Cs}$ and ${ }^{85} \mathrm{Sr}$ from MVST simulant solutions. The MVST solutions are $>4 \underline{\mathrm{M}}$ in sodium and 0.25 to $1 \underline{\mathrm{M}}$ in potassium, which present problems in removing the small quantities of cesium and strontium $\left(10^{-4}\right.$ to $\left.10^{-7} \underline{\mathrm{M}}\right)$ from solution.

The previous reports ${ }^{13,14}$ have included results from both batch distribution coefficient measurements and small ion-exchange column tests, using the resorcinol-based resin developed at the Savannah River Site and the Duolite CS-100. Since these resins were relatively ineffective for strontium removal, several other organic ion-exchange resins reported to be effective for strontium removal were tested. 


\subsubsection{Experimental Methods}

The data obtained for organic ion-exchange resins resulted from both batch contacts of the sorbent with the appropriate solution and small, continuous ion-exchange column tests. In most cases, the simulant solution was as described in Sect. 2.1.1, based on analysis of MVST W-29. The solution was spiked with cesium using a small amount of actual W-29 supernate $\left({ }^{137} \mathrm{Cs}\right.$ predominant) and with strontium using ${ }^{85} \mathrm{Sr}$ tracer. Solutions were adjusted to the specified $\mathrm{pH}$ prior to the test and usually checked afterward; in most cases, changes resulting from the ion-exchange contacts were small. Orion Research Model $811 \mathrm{pH}$ meters were used.

Batch contacts of sorbent and solution took place in centrifuge cones using a "RotoTorque" rotating mixer. The rotational speed and the tilt angle were adjusted by experiment to give good mixing even with fairly large sorbent particles. After mixing for predetermined times had been completed, the cones were removed and the resin was allowed to settle prior to sampling. Samples of the clarified supernate (usually $2 \mathrm{~mL}$ ) were removed with a pipetter and transferred to sample vials for counting. During batch tests when successive samples were removed from the same centrifuge cone, the values of $C_{o}$ and $\mathrm{V}$ were recalculated after each sample was withdrawn, taking into account the measured concentration and volume of the sample. The samples were counted using a NaI well counter with a LBK Wallack Compugamma analysis system. Although only relative counts are used in this work, the counters were calibrated against counting standards.

Colurnn experiments were conducted in a $1-\mathrm{cm}$-diam, 50 -mL-capacity burette with a porous glass frit at the bottom to support the resins tested. Volumes of 3 to $5 \mathrm{~mL}$ of resin were used, and flow rates through the bed were controlled by a Cole-Parmer tubing pump at 0.25 to $1.25 \mathrm{~mL} / \mathrm{min}$, depending on the test. Fractions of the column throughput were collected using a fraction collector holding twenty-five 75-mL-capacity tubes. Two-milliliter samples were removed from the tubes for determination of the ${ }^{137} \mathrm{Cs}$ and ${ }^{85} \mathrm{Sr}$ activities that had come through the column. When the eluent activity had reached at least $50 \%$ of the feed concentration, the run was terminated and the resin was eluted with 2 or $4 \underline{M}$ formic acid, 1 or $2 \underline{\mathrm{M}} \mathrm{HCl}$, or $0.5 \underline{\mathrm{M}} \mathrm{HNO}_{3}$.

As described in Sect. 2.1.1, the results of the experiments can be expressed by several different parameters that relate to the decontamination effectiveness. For resin batch experiments, the distribution coefficient, $\mathrm{K}_{\mathrm{d}}[\mathrm{Eq} .(1)]$ is used based on the dry mass of the resin. Dry samples of the resins were obtained by washing the resins twice with ten resin 
volumes of $2 \underline{M}$ formic acid, twice with ten resin volumes of distilled water, five times with six resin volumes of $0.25 \underline{\mathrm{M} \mathrm{NaOH}}$, and then three times with ten resin volumes of distilled water. After being washed, the resins were air dried overnight on blotter paper. When the data obtained using the ion-exchange columns were analyzed, the distribution coefficient was based on the volume of resin present in the column: ${ }^{19}$

$$
\mathrm{K}_{\mathrm{d}}{ }^{\mathrm{V}}=\left(\mathrm{C}_{\mathrm{o}}-\mathrm{C}\right) \mathrm{V} / \mathrm{CV}_{\text {resin }}=\mathrm{K}_{\mathrm{d}} \rho,
$$

where $\rho$ is the tap density of the wet resin bed ( $g$ dry resin/mL resin bed) and $V_{\text {resin }}$ is the wet-volume resin used in the column. The values of $\mathrm{K}_{d}{ }^{\mathrm{v}}$ were obtained from the breakthrough curves plotted on a probability-log graph of $C / C_{0}$ vs the column throughput in resin volumes. The maximum capacity of the resin for the ion of interest is related to the resin volumes of feed passed through the column when $-50 \% \mathrm{C} / \mathrm{C}_{0}$ occurs and is approximately the $\mathrm{K}_{d} \mathrm{v}$. The slope of the breakthrough curve is related to the ion-exchange kinetics of the resin.

\subsubsection{Cesium and Strontium Removal with Chelating Resins}

Several chelating resins were acquired for testing since they are expected to be particularly effective for the removal of polyvalent metals such as ${ }^{90} \mathrm{Sr}$, as well as rare earths and actinides. These have been tested extensively by measuring $K_{d} s$ in batch experiments and, to a much more limited extent, in column tests. The chelating resins tested appear adequate for strontium removal tasks.

\subsubsection{Batch Tests}

Several organic chelating ion-exchange resins have been obtained for study to remove

${ }^{90} \mathrm{Sr}$ from various waste solutions. They include Amberlite ${ }^{\bullet}$ IRC-718 (Rohm \& Haas), Ionac ${ }^{\bullet}$ SR-5 (Sybron Chemicals, Inc.), and Lewatit ${ }^{\bullet}$ TP 207 and TP 208 (Bayer AG); all were $-16+50$ mesh. These four, plus the SRS and Duolite ${ }^{\bullet} \mathrm{CS}-100$ resins, were run in batch tests to determine the $\mathrm{K}_{\mathrm{d}} \mathrm{s}$ at a phase ratio of 150 (150 mi aqueous $/ 1 \mathrm{~g}$ resin) using the standard W-29 simulant described in Sect. 2.1.1 and containing W-29 supernate and ${ }^{85} \mathrm{Sr}$ as tracers. Tests were conducted on undiluted simulant, as well as solutions of 1 part simulant plus 1 part water and 1 part simulant plus 3 parts water. The $\mathrm{K}_{d} \mathrm{~s}$ for ${ }^{85} \mathrm{Sr}$ removal using IRC-718, SR-5, TP-207, and TP-208 are shown in Table 13. With simulant solutions and dilutions that contained $4.58,2.29$, and $1.145 \underline{\mathrm{M}}$ sodium, $0.25,0.125$, and $0.0625 \underline{\mathrm{M}}$ 
Table 13. Batch $\mathrm{Sr}$ and $\mathrm{Cs} \mathrm{K}_{\mathrm{s}} \mathrm{s}$ with simulant $(\mathrm{Na}=4.58 \underline{\mathrm{M}}, \mathrm{K}=0.25 \underline{\mathrm{M}}$, $\mathrm{pH}=129,150 \mathrm{~L} / \mathrm{kg}$ resin)

\begin{tabular}{|c|c|c|c|c|c|c|c|}
\hline \multirow[b]{2}{*}{ Resin } & \multirow[b]{2}{*}{ Dil. } & \multicolumn{2}{|c|}{ 1-h contact } & \multicolumn{2}{|c|}{ 24-h contact } & \multicolumn{2}{|c|}{ 48- to 72-h contact } \\
\hline & & $\mathrm{K}_{\mathrm{d}} \mathrm{Sr}$ & $\mathrm{K}_{\mathrm{d}} \mathrm{Cs}$ & $\underline{\mathrm{K}}_{d} \mathrm{Sr}$ & $\underline{\mathrm{K}_{d} \mathrm{Cs}}$ & $\mathrm{K}_{\mathrm{d}} \mathrm{Sr}$ & $\mathrm{K}_{\mathrm{d} C \mathrm{Cs}}$ \\
\hline IRC-718 & $\begin{array}{l}0 \\
1: 1 \\
1: 3\end{array}$ & $\begin{array}{r}940 \\
1990 \\
4300\end{array}$ & $\begin{array}{l}0 \\
0 \\
0\end{array}$ & $\begin{array}{r}5420 \\
11315 \\
23070\end{array}$ & $\begin{array}{l}0 \\
0 \\
0\end{array}$ & $\begin{array}{r}6110 \\
11300 \\
23480\end{array}$ & $\begin{array}{l}0 \\
0 \\
0\end{array}$ \\
\hline SR-5 & $\begin{array}{l}0 \\
1: 1 \\
1: 3\end{array}$ & $\begin{array}{c}350 \\
890 \\
1780\end{array}$ & $\begin{array}{l}0 \\
0 \\
0\end{array}$ & $\begin{array}{r}1760 \\
4690 \\
12900\end{array}$ & $\begin{array}{l}0 \\
0 \\
0\end{array}$ & $\begin{array}{c}2050 \\
5075 \\
13830\end{array}$ & $\begin{array}{l}0 \\
0 \\
0\end{array}$ \\
\hline TP-207 & $\begin{array}{l}0 \\
1: 1 \\
1: 3\end{array}$ & $\begin{array}{c}690 \\
910 \\
3250\end{array}$ & $\begin{array}{l}0 \\
0 \\
0\end{array}$ & $\begin{array}{c}5415 \\
13600 \\
31780\end{array}$ & $\begin{array}{l}0 \\
0 \\
0\end{array}$ & $\begin{array}{c}10050 \\
21080 \\
29170\end{array}$ & $\begin{array}{l}0 \\
0 \\
0\end{array}$ \\
\hline TP-208 & $\begin{array}{l}0 \\
1: 1 \\
1: 3\end{array}$ & $\begin{array}{c}390 \\
1280 \\
4100\end{array}$ & $\begin{array}{l}0 \\
0 \\
0\end{array}$ & $\begin{array}{c}3890 \\
15900 \\
33550\end{array}$ & $\begin{array}{l}0 \\
0 \\
0\end{array}$ & $\begin{array}{r}6480 \\
17240 \\
25890\end{array}$ & $\begin{array}{l}0 \\
0 \\
0\end{array}$ \\
\hline CS-100 & $\begin{array}{l}0 \\
1: 1 \\
1: 3\end{array}$ & $\begin{array}{c}95 \\
170 \\
500\end{array}$ & $\begin{array}{c}35 \\
210 \\
120\end{array}$ & $\begin{array}{c}563 \\
260 \\
1600\end{array}$ & $\begin{array}{c}100 \\
65 \\
195\end{array}$ & $\begin{array}{c}270 \\
590 \\
1720\end{array}$ & $\begin{array}{c}55 \\
104 \\
190\end{array}$ \\
\hline SRS ${ }^{\mathbf{a}}$ & $\begin{array}{l}0 \\
1: 1 \\
1: 3 \\
\end{array}$ & $\begin{array}{l}155 \\
340 \\
930 \\
\end{array}$ & $\begin{array}{r}330 \\
930 \\
2350 \\
\end{array}$ & $\begin{array}{c}180 \\
390 \\
1070 \\
\end{array}$ & $\begin{array}{l}1120 \\
2370 \\
5290 \\
\end{array}$ & $\begin{array}{c}190 \\
410 \\
1170 \\
\end{array}$ & $\begin{array}{l}1130 \\
2140 \\
4490 \\
\end{array}$ \\
\hline
\end{tabular}

80-100 mesh.

potassium, and had $\mathrm{pHs}$ of $12.9,12.7$, and 12.5 , TP-207 resin was slightly superior at long contact times $(48 \mathrm{~h})$; however, IRC-718 was slightly superior at short contact times $(1 \mathrm{~h})$.

The five resins, SRS, IRC-718, TP-207, TP-208, and SR-5, were also tested with the simulant solution at $\mathrm{pH} 12.7$ and a phase ratio of $\approx 1500$ (10 mg resin to $15 \mathrm{~mL}$ liquid) to determine whether some ion present at low concentration might interfere by loading in preference to the cesium or strontium. The results are shown in Table 14. The $\mathrm{K}_{\mathrm{d}} \mathrm{s}$ for strontium after a 72 -h contact at pH 12.7 were 2900 for TP-207, 2500 for TP-208, 3600 for IRC-718, 1440 for SR-5, and 235 for SRS.

The same resins and feed materials were also tested at a phase ratio of 1500:1 at $\mathrm{pH}$ 12.3, 10.7, and 10.3 (Table 14). The highest and lowest $\mathrm{K}_{\mathrm{d}} \mathrm{s}$ occurred at $\mathrm{pH} 10.7$ and 12.3, respectively, and the values varied between 1850 and 930 for SR-5, 4570 and 1100 for 
Table 14. Batch strontium and cesium $K_{d}$ data for chelating and SRS resins (phase ratio: $1500 \mathrm{~L}$ liquid/kg resin)

\begin{tabular}{|c|c|c|c|c|c|c|c|c|c|}
\hline \multirow[b]{2}{*}{$\underline{\text { Resin }}$} & \multicolumn{3}{|c|}{ Conditions } & \multicolumn{3}{|c|}{$\underline{K}, \mathrm{~s}$ for $\mathrm{Sr}$ at contact times of: } & \multicolumn{3}{|c|}{$\mathrm{K} s$ for $\mathrm{Cs}$ at contact times of: } \\
\hline & $\mathrm{pH}$ & $\mathrm{Na}(\mathrm{M})$ & $\mathrm{K}(\mathrm{M})$ & $1 \mathrm{~h}$ & $24 \mathrm{~h}$ & $48 \mathrm{~h}$ & $1 \mathrm{~h}$ & $24 \mathrm{~h}$ & $48 \mathrm{~h}$ \\
\hline TP-207 & 12.7 & 4.58 & 0.25 & 241 & 1695 & 2922 & 29 & 1 & 0 \\
\hline TP-208 & & & & 285 & 1702 & 2508 & 0 & 0 & 0 \\
\hline IRC-718 & & & & 456 & 2268 & 3594 & 2 & 0 & 0 \\
\hline SR-5 & & & & 246 & 1105 & 1440 & 0 & 3 & 0 \\
\hline SRS & & & & 147 & 204 & 235 & 237 & 665 & 522 \\
\hline TP-207 & 12.3 & 4.58 & 0.25 & 185 & 1068 & 1654 & 0 & 0 & 0 \\
\hline TP-208 & & & & 192 & 1354 & 2238 & 0 & 0 & 0 \\
\hline IRC-718 & & & & 324 & 1145 & 1098 & 0 & 0 & 0 \\
\hline SR-5 & & & & 175 & 775 & 936 & $\mathbf{0}$ & 0 & 0 \\
\hline SRS & & & & 124 & 136 & 179 & 226 & 699 & 593 \\
\hline TP-207 & 10.68 & 4.58 & 0.25 & 231 & 3885 & 8064 & 0 & 0 & 0 \\
\hline TP-208 & & & & 283 & 3837 & 6866 & 0 & 0 & 0 \\
\hline IRC-718 & & & & 325 & 3210 & 4570 & 0 & 0 & 0 \\
\hline SR-5 & & & & 194 & 1368 & 1846 & 0 & 0 & 0 \\
\hline SRS & & & & 38 & 37 & 51 & 199 & 565 & 388 \\
\hline TP-207 & 10.26 & 4.58 & 0.25 & 218 & 2691 & 5492 & 23 & 0 & 14 \\
\hline TP-208 & & & & 219 & 2520 & 4470 & 21 & 4 & 3 \\
\hline IRC-718 & & & & 382 & 2962 & 3777 & 14 & 0 & 0 \\
\hline SR-5 & & & & 212 & 1277 & 1705 & 28 & 2 & 17 \\
\hline SRS & & & & 60 & 54 & 56 & 224 & 557 & 358 \\
\hline
\end{tabular}

IRC-718, 8060 and 1650 for TP-207, and 6860 and 2240 for TP-208; however, the $\mathrm{K}_{\mathrm{d}}$ increased above $\mathrm{pH} 12.3$ and decreased below $\mathrm{pH}$ 10.7. For SRS resin, the strontium $\mathrm{K}_{\mathrm{d}}$ decreased from 180 at $\mathrm{pH} 12.3$ to 50 at $\mathrm{pH} 10.3$. Both types of resins appear to be effective over a fairly wide $\mathrm{pH}$ range for the MVST supernate simulant. In addition to these results, samples taken at $1 \mathrm{~h}$ and $24 \mathrm{~h}$ of batch mixing for all $\mathrm{pH}$ leveis indicate that significant time ( $>24 \mathrm{~h}$ ) is required for equilibrium to be reached. Data for 24 and $72 \mathrm{~h}$ indicate that the exchange is slower at the lower pHs.

The removal of cesium was essentially zero for each of the four chelating resins under all conditions. In contrast, the SRS resin and CS-100 were effective for cesium removal. With the phase ratio of 150 , cesium $K_{d} s$ were 1130 and 55 with the SRS and CS-100 resins, 
respectively. At a phase ratio of 1500 , the cesium $\mathrm{K}_{d}$ for the SRS resin decreased from about 590 to 360 as the $\mathrm{pH}$ was decreased from 12.3 to 10.3 (Table 14), and the $\mathrm{K}_{d}$ observed after $24 \mathrm{~h}$ was larger than that after $72 \mathrm{~h}$.

\subsubsection{Simultaneous Cesium and Strontium Removal with Mixed-Resin Column}

Both the chelating resin, Amberlite IRC-718, and the SRS resin were effective in simultaneous removal of both cesium and strontium in a mixed-resin bed column test. A column test with $2.0 \mathrm{~mL}$ of IRC-718 and $2.6 \mathrm{~mL}$ of SRS 80-100 mesh resin (dry volume, corresponding to about 0.72 and $2.17 \mathrm{~g}$, respectively) in a mixed bed with W-29 simulant containing ${ }^{85} \mathrm{Sr}$ and MVST supernate for strontium and cesium tracing was operated for about 372 column volumes (CV) (based on the total wet resin volume of $7 \mathrm{~mL}$ ). The breakthrough curves are shown in Fig. 1. Both strontium and cesium exceeded $50 \%$ breakthrough at the end of the run. Fifty percent breakthrough occurred at about $240 \mathrm{CV}$ for cesium and at about $350 \mathrm{CV}$ for strontium. The column residence time was about 15 min, which is one-half to one-fourth of the residence time required for a sharp, more vertical breakthrough curve. The results show that a slightly smaller fraction of the chelating resin would be needed to allow the more nearly simultaneous breakthrough of both cesium and strontium. The combination of the two resins does, indeed, remove both cesium and strontium, and column capacities are acceptable on an operational basis. The $\mathrm{K}_{d} \mathrm{~s}$ calculated from the breakthrough curves compare favorably with those measured in batch tests for both strontium with IRC-718 and cesium with SRS resin.

The elution of the resin used in the column run was completed, and the resin showed very little remaining activity. Less than $1 \%$ of the strontium and cesium activity was left on the resin, and a mass balance showed a recovery of $97.3 \%$ of the cesium activity and $99.85 \%$ of the strontium activity that had loaded. A total of 19 resin volumes of $2 \underline{M}$ formic acid was used. The elution was performed very slowly with a flow rate of about one resin volume per day. Previous resin elutions were conducted much faster (1 resin volume per 5- to 15 -min period) and resulted in the incomplete recovery of activity. ${ }^{13}$

\subsection{Source Treatment Studies of Aluminum Decladding Solutions}

There is increasing interest in treating certain highly active wastes at their source rather than mixing them with a very much larger volume of low-activity waste containing large amounts of salts. One important waste is generated by dissolution of the aluminum 


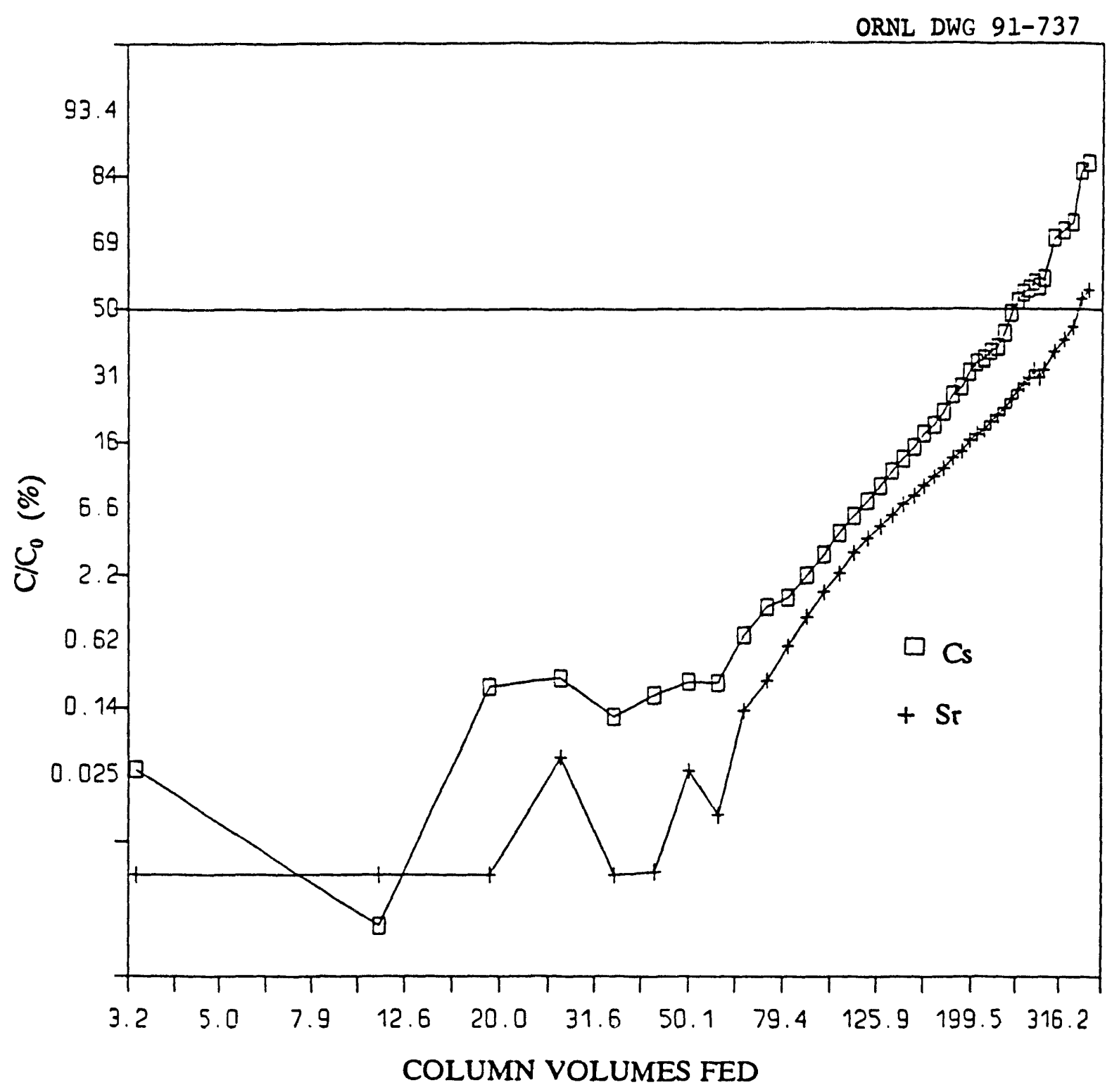

Fig. 1. Breakthrough curves for mixed IRC-718 plus SRS resin column. 
associated with aluminum-clad actinide oxide cermet irradiation targets at the Radiochemical Engineering Development Center (REDC). The caustic solution contains large amounts of aluminum and ${ }^{137} \mathrm{Cs}$ activity, plus some ${ }^{90} \mathrm{Sr}$, but almost no actinides. The waste is expected to contain the composition shown in Table 15. Removal of cesium and strontium from this waste would substantially decrease the cesium input into the LLLW system anticipated over the next few years.

Batch equilibrium measurements of distribution coefficients with $\mathrm{NaT}, \mathrm{KCoFC}$, and the SRS resin were conducted on the REDC waste stream simulant. Synthetic solutions without the radioactive components were traced with W-29 supernate for ${ }^{137} \mathrm{Cs}$ and ${ }^{85} \mathrm{Sr}$ for analysis by gamma counting. Solutions at full strength, diluted two parts solution to one part water, one part solution to one part water, one part solution to two parts water, and one part solution to three parts water $(1.055,0.703,0.528,0.352$, and $0.264 \underline{\mathrm{M}}$ sodium aluminate, respectively) were prepared. Because of the effect of $\mathrm{pH}$ on aluminum solubility, concentrated nitric acid was added to adjust the $\mathrm{pH}$ of these solutions, in intervals of $0.2 \mathrm{pH}$ unit, to values calculated to be between 14.1 and 13.1 . The measured $\mathrm{pH}$ range was 13.7 to 12.8 .

Results of these tests are shown in Table 16 for the inorganic ion exchangers. Two of the solutions, at zero and 1:1 dilution, were tested for strontium removal by adding about $700 \mathrm{ppm}$ of sodium titanate exchanger at the calculated pHs of 14.11 and 13.81 . All five dilutions, at a calculated $\mathrm{pH}$ of 13.1 , were tested for the removal of both cesium and strontium by adding a combination of $700 \mathrm{ppm}$ sodium titanate and 500 to $600 \mathrm{ppm}$ of KCoFC prepared according to the Savannah River method, dried at $100^{\circ} \mathrm{F}$, and sized to 100-230 mesh. Results at all conditions and times showed promising decontaminations. After $72 \mathrm{~h}$, the KCoFC still retained the ${ }^{137} \mathrm{Cs}$ that had been picked up at shorter mixing times, even though the $\mathrm{pH}$ was about 13 . The heat-treated KCoFC was stable in pH 13 REDC-simulated waste solution for at least $3 \mathrm{~d}$.

The five dilutions were tested with two particle sizes of the SRS resin, $60-80$ mesh and 120-140 mesh, to determine whether particle size had any effect on the strontium and cesium uptakes. Results at $72 \mathrm{~h}$ mixing time are shown in Table 17. The results for cesium removal show that (1) the larger-size resin was more effective, by an order of magnitude, than the smaller size; and (2) there was no large change in the ratio with dilution, although the $K_{d}$ for the larger-size particles tended to increase as the dilution increased while the $K_{d}$ for the smaller-size particles was almost constant with dilution, even showing a slight 
Table 15. Expected composition of aluminum target dissolution waste

\begin{tabular}{lc}
\hline Species & Concentration \\
\hline & $\frac{\underline{\mathrm{M}}}{1.054}$ \\
$\mathrm{NaAlO}_{2}$ & 1.298 \\
$\mathrm{NaOH}^{\mathrm{NaNO}}{ }_{3}$ & 0.469 \\
\hdashline $\mathrm{pH}$ & 14.1 \\
& $\underline{\mathrm{Ci} / \mathrm{L}}$ \\
${ }^{134} \mathrm{Cs}$ & 2.9 \\
${ }^{137} \mathrm{Cs}$ & 6.7 \\
${ }^{90} \mathrm{Sr}$ & 0.11 \\
${ }^{125} \mathrm{Sb}$ & 0.12 \\
${ }^{106} \mathrm{Ru}$ & 0.009 \\
\hline
\end{tabular}

decrease at the highest dilution. In contrast, strontium removal was very similar with the two resin sizes and $\mathrm{K}_{d}$ showed a uniform increase with dilution. The behavior of strontium was expected, but that of cesium was not. No reason is known for the effect of particle size on cesium distribution.

The 60-80 mesh SRS resin was also tested at other $\mathrm{pH}$ levels with each dilution for cesium and strontium removal; the results are shown in Table 18. In the zero-dilution, lowest-pH case, a white precipitate (probably an aluminum compound) formed after a few hours and may have interfered slightly with the removal of cesium. This test condition was not rerun. All the strontium was essentially removed in this one test, but in no other, so the precipitation may have been responsible for the very large $\mathrm{K}_{d}$ for strontium. The resin removed almost all the cesium under all conditions, and increasingly more strontium as the dilution increased. As the $\mathrm{pH}$ decreased, with each dilution, there was a decrease in $\mathrm{K}_{\mathrm{d}}$ for cesium and an increase in the strontium $\mathrm{K}_{\mathrm{d}}$. The MVST simulant was not tested in this high-pH range, so comparisons between the results on the two different streams are not meaningful. It should be noted that these $\mathrm{K}_{\mathrm{d}}$ values are large enough to make a batch process practical. The batch approach could be advantageous because of the difficulty with column operations, resulting from possible precipitation of aluminum during processing. 
Table 16. Cesium and strontium removal from caustic aluminate solution with inorganic sorbents

\begin{tabular}{|c|c|c|c|c|c|c|c|c|}
\hline Exchanger ${ }^{a}$ & $\begin{array}{c}\text { Contact } \\
\text { time } \\
\text { (h) } \\
\end{array}$ & $\begin{array}{c}\mathrm{Al} / \mathrm{OH} / \mathrm{NO}_{3} \\
(\mathrm{M})\end{array}$ & $\frac{p}{\text { Value }}$ & $\frac{\mathrm{H}}{\text { Condition }}$ & $\mathrm{n}^{\mathrm{b}} \mathrm{Sr} \mathrm{K}$ & Cs $K_{d}$ & $\begin{array}{c}\mathrm{Sr} \\
\mathrm{Rem} . \\
(\%)\end{array}$ & $\begin{array}{c}\text { Cs } \\
\text { Rem. } \\
(\%)\end{array}$ \\
\hline NaTi-0 & $\begin{array}{l}I \\
1 \\
24 \\
72\end{array}$ & $\begin{array}{l}1.055 \\
1.298 \\
0.469\end{array}$ & $\begin{array}{l}14.11 \\
13.71 \\
13.69\end{array}$ & $\begin{array}{l}\text { C } \\
B \\
E\end{array}$ & $\begin{array}{r}8650 \\
110961 \\
104565\end{array}$ & $\begin{array}{l}32 \\
20 \\
15\end{array}$ & $\begin{array}{l}85.09 \\
98.70 \\
98.61\end{array}$ & $\begin{array}{l}2.05 \\
1.10 \\
0.55\end{array}$ \\
\hline TiFC-0 & $\begin{array}{l}\text { I } \\
1 \\
24 \\
72\end{array}$ & $\begin{array}{l}0.982 \\
0.122 \\
1.523\end{array}$ & $\begin{array}{l}13.09 \\
13.00 \\
12.97\end{array}$ & $\begin{array}{l}\text { C } \\
B \\
E\end{array}$ & $\begin{array}{r}8317 \\
39372 \\
67083\end{array}$ & $\begin{array}{l}12474 \\
36627 \\
34153\end{array}$ & $\begin{array}{l}78.22 \\
94.60 \\
96.78\end{array}$ & $\begin{array}{l}85.64 \\
94.67 \\
94.30\end{array}$ \\
\hline TiFC-2:1 & $\begin{array}{l}I \\
1 \\
24 \\
72\end{array}$ & $\begin{array}{l}0.672 \\
0.124 \\
1.002\end{array}$ & $\begin{array}{l}13.09 \\
13.01 \\
12.96\end{array}$ & $\begin{array}{l}C \\
B \\
E\end{array}$ & $\begin{array}{r}26958 \\
214881 \\
327316\end{array}$ & $\begin{array}{l}36317 \\
89140 \\
64187\end{array}$ & $\begin{array}{l}92.73 \\
99.03 \\
99.37\end{array}$ & $\begin{array}{l}94.51 \\
97.69 \\
96.83\end{array}$ \\
\hline NaTi-1:1 & $\begin{array}{l}I \\
1 \\
24 \\
72\end{array}$ & $\begin{array}{l}0.528 \\
0.649 \\
0.235\end{array}$ & $\begin{array}{l}13.81 \\
13.57 \\
13.50\end{array}$ & $\begin{array}{l}\mathrm{C} \\
\mathrm{B} \\
\mathrm{E}\end{array}$ & $\begin{array}{c}11973 \\
108884 \\
96761\end{array}$ & $\begin{array}{l}23 \\
31 \\
38\end{array}$ & $\begin{array}{l}89.47 \\
98.75 \\
98.60\end{array}$ & $\begin{array}{l}1.60 \\
2.25 \\
3.07\end{array}$ \\
\hline TiFC-1:1 & $\begin{array}{l}I \\
1 \\
24 \\
72\end{array}$ & $\begin{array}{l}0.511 \\
0.124 \\
0.731\end{array}$ & $\begin{array}{l}13.10 \\
13.00 \\
12.96\end{array}$ & $\begin{array}{l}\mathrm{C} \\
\mathrm{B} \\
\mathrm{E}\end{array}$ & $\begin{array}{c}33825 \\
169589 \\
263839\end{array}$ & $\begin{array}{l}31064 \\
78141 \\
67093\end{array}$ & $\begin{array}{l}95.21 \\
99.01 \\
99.37\end{array}$ & $\begin{array}{l}94.80 \\
97.88 \\
97.53\end{array}$ \\
\hline $\mathrm{T}_{1} \mathrm{FC}-1: 2$ & $\begin{array}{l}\text { I } \\
1 \\
24 \\
72\end{array}$ & $\begin{array}{l}0.345 \\
0.127 \\
0.451\end{array}$ & $\begin{array}{l}13.10 \\
12.99 \\
12.97\end{array}$ & $\begin{array}{l}\text { C } \\
B \\
E\end{array}$ & $\begin{array}{c}37908 \\
204746 \\
219437\end{array}$ & $\begin{array}{c}33249 \\
120784 \\
96335\end{array}$ & $\begin{array}{l}94.67 \\
98.97 \\
99.04\end{array}$ & $\begin{array}{l}93.99 \\
98.28 \\
97.85\end{array}$ \\
\hline TiFC-1:3 & $\begin{array}{l}\text { I } \\
1 \\
24 \\
72 \\
\end{array}$ & $\begin{array}{l}0.261 \\
0.128 \\
0.308\end{array}$ & $\begin{array}{l}13.10 \\
13.01 \\
13.02\end{array}$ & $\begin{array}{l}\text { C } \\
B \\
E\end{array}$ & $\begin{array}{r}20372 \\
112871 \\
154491 \\
\end{array}$ & $\begin{array}{r}20218 \\
114918 \\
120919\end{array}$ & $\begin{array}{l}91.97 \\
98.47 \\
98.88 \\
\end{array}$ & $\begin{array}{l}91.91 \\
98.48 \\
98.56\end{array}$ \\
\hline
\end{tabular}


Table 17. Comparison of $60-80$ mesh with $120-140$ mesh SRS resin using simulated aluminate waste (72-h contact)

\begin{tabular}{|c|c|c|c|c|c|c|c|c|c|c|}
\hline \multirow[t]{2}{*}{$\begin{array}{l}\text { Resin } \\
\text { size } \\
\text { (mesh) }\end{array}$} & \multirow[t]{2}{*}{$\begin{array}{c}\text { Phase } \\
\text { ratio } \\
\text { ( } \mu \text { L:mg) }\end{array}$} & \multirow[t]{2}{*}{ Dilution } & \multirow[t]{2}{*}{$\begin{array}{l}\text { Calc. } \\
\mathrm{pH}\end{array}$} & \multirow{2}{*}{ 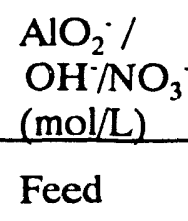 } & $\frac{\text { Coun }}{\mathrm{Sr}}$ & $\frac{\mathrm{ts} / \mathrm{min}}{\mathrm{Cs}}$ & \multirow[t]{2}{*}{$\operatorname{Sr} \mathbf{K}_{d}$} & \multirow[t]{2}{*}{ Cs $K_{d}$} & \multirow[t]{2}{*}{$\begin{array}{l}\text { Sr } \\
\text { Rem. } \\
(\%) \\
\end{array}$} & \multirow[t]{2}{*}{$\begin{array}{l}\text { Cs } \\
\text { Rem. } \\
(\%)\end{array}$} \\
\hline & & & & & -6000 & -4500 & & & & \\
\hline $60-80$ & 170 & 0 & 14.11 & $\begin{array}{l}1.055 \\
1.298\end{array}$ & 1673 & 16 & 375 & 37854 & 72.44 & 99.63 \\
\hline $120-140$ & 169 & 0 & & 0.469 & 1410 & 192 & 470 & 3163 & 76.53 & 95.76 \\
\hline $60-80$ & 173 & $2: 1$ & 13.94 & $\begin{array}{l}0.703 \\
0.865\end{array}$ & 1126 & 15 & 605 & 43322 & 80.55 & 99.67 \\
\hline $120-140$ & 175 & $2: 1$ & & 0.313 & 1100 & 198 & 683 & 3161 & 82.00 & 95.60 \\
\hline $60-80$ & 176 & $1: 1$ & 13.81 & $\begin{array}{l}0.528 \\
0.649\end{array}$ & 873 & 10 & 882 & 66872 & 85.59 & 99.78 \\
\hline $120-140$ & 169 & $1: 1$ & & 0.235 & 869 & 190 & 870 & 3221 & 85.64 & 95.79 \\
\hline $60-80$ & 173 & $1: 2$ & 13.64 & $\begin{array}{l}0.352 \\
0.433\end{array}$ & 592 & 14 & 1340 & 45374 & 90.16 & 99.68 \\
\hline $120-140$ & 171 & $1: 2$ & & 0.156 & 636 & 206 & 1246 & 3012 & 89.49 & 95.46 \\
\hline $60-80$ & 170 & $1: 3$ & 13.51 & $\begin{array}{l}0.264 \\
0.325\end{array}$ & 442 & 7 & 1835 & 89655 & 92.74 & 99.84 \\
\hline $120-140$ & 173 & $1: 3$ & & 0.117 & 532 & 244 & 1524 & 2749 & 91.17 & 94.98 \\
\hline
\end{tabular}


Table 18. Removal of cesium and strontium from simulatea aluminate waste using 60-80 mesh particle size SRS resin (72-h contact)

\begin{tabular}{|c|c|c|c|c|c|c|c|c|c|}
\hline \multirow[t]{2}{*}{ Dilution } & $\begin{array}{l}\text { Phase } \\
\text { ratio } \\
\text { ( } \mu \text { L:mg }\end{array}$ & $\begin{array}{r}\text { Calc. } \\
\perp \mathrm{pH}\end{array}$ & $\begin{array}{l}\mathrm{AlO}_{2}^{-} \\
(\mathrm{mol} / \mathrm{L}\end{array}$ & $\frac{\text { Count }}{\mathrm{Sr}}$ & $\frac{\min }{\mathrm{Cs}}$ & \multirow[t]{2}{*}{$\mathrm{Sr} \mathrm{K}_{\mathrm{d}}$} & \multirow[t]{2}{*}{ Cs $K_{d}$} & \multirow[t]{2}{*}{$\begin{array}{c}\text { Sr Rem. } \\
(\%)\end{array}$} & \multirow[t]{2}{*}{$\begin{array}{c}\text { Cs Rem } \\
(\%)\end{array}$} \\
\hline & \multicolumn{2}{|l|}{ Feed } & & \multicolumn{2}{|c|}{$\approx 6000 \approx 4500$} & & & & \\
\hline \multirow[t]{6}{*}{0} & 170 & 14.11 & 1.055 & 1673 & 16 & 375 & 3785 & 72.44 & 99.63 \\
\hline & 179 & 13.90 & 1.024 & 1425 & 19 & 467 & 35070 & 75.68 & 99.57 \\
\hline & 179 & 13.67 & 1.005 & 1255 & 17 & 530 & 36922 & 77.98 & 99.60 \\
\hline & 185 & 13.48 & 0.993 & 1183 & 25 & 574 & 25779 & 78.91 & 99.41 \\
\hline & 188 & 13.28 & 0.987 & 1223 & 25 & 555 & 25445 & 78.09 & 99.40 \\
\hline & 183 & 13.09 & 0.982 & $2^{a}$ & 31 & $442087^{a}$ & 19062 & 99.96 & 99.22 \\
\hline \multirow[t]{5}{*}{$2: 1$} & 173 & 13.94 & 0.703 & 126 & 15 & 605 & 43322 & 80.55 & 99.67 \\
\hline & 176 & 13.70 & 0.688 & 954 & 14 & 766 & 45647 & 83.79 & 99.68 \\
\hline & 179 & 13.50 & 0.680 & 827 & 21 & 887 & 30568 & 85.54 & 99.52 \\
\hline & 181 & 13.29 & 0.675 & 786 & 27 & 925 & 23517 & 86.07 & 99.36 \\
\hline & 179 & 13.09 & 0.672 & 810 & 17 & 892 & 36904 & 85.75 & 99.60 \\
\hline \multirow[t]{5}{*}{$1: 1$} & 176 & 13.81 & 0.528 & 873 & 10 & 882 & 66872 & 85.59 & 99.78 \\
\hline & 173 & 13.71 & 0.523 & 749 & 12 & 1025 & 57365 & 87.52 & 99.75 \\
\hline & 176 & 13.50 & 0.517 & 665 & 14 & 1170 & 47211 & 88.80 & 99.69 \\
\hline & 181 & 13.30 & 0.513 & 612 & 13 & 1290 & 49934 & 89.51 & 99.71 \\
\hline & 180 & 13.10 & 0.511 & 659 & 19 & 1160 & 35028 & 88.52 & 99.58 \\
\hline \multirow[t]{4}{*}{$1: 2$} & 173 & 13.64 & 0.352 & 592 & 14 & 1340 & 45374 & 90.16 & 99.68 \\
\hline & 175 & 13.51 & 0.349 & 512 & 12 & 1561 & 53975 & 91.36 & 99.73 \\
\hline & 176 & 13.30 & 0.347 & 443 & 17 & 1856 & 38676 & 92.62 & 99.62 \\
\hline & 177 & 13.10 & 0.345 & 461 & 17 & 1749 & 39364 & 92.15 & 99.63 \\
\hline \multirow[t]{3}{*}{ 1:3 } & 170 & 13.51 & 0.264 & 442 & 7 & 1835 & 89655 & 92.74 & 99.84 \\
\hline & 172 & 13.31 & 0.262 & 375 & 11 & 2203 & 58052 & 93.85 & 99.76 \\
\hline & 174 & 13.11 & 0.261 & 368 & 35 & 2234 & 19171 & 93.85 & 99.25 \\
\hline
\end{tabular}

${ }^{a}$ White precipitate formed. 


\subsection{CROSS-FLOW FILTRATION TESTS}

Membrane separation technologies are used in the nuclear waste industry because they lend themselves to continuous processing, modular design, low energy use, and low maintenance requirements; in adaition, they have broad applicability for a wide range of pollution control problems. ${ }^{20}$ Cross-flow or tangential flow filtration allows for continuous processing because the bulk solution flows over and parallel to the membrane surface. System pressure forces pirt of the liquid through the membrane, and turbulence minimizes the accumulation of particulate matter on the membrane surface. Three classifications of cross-flow filtration membranes are used, depending on the particle size of the materials rejected. Microfiltration removes particulates from 0.1 to $10 \mu \mathrm{m}$. Ultrafiltration separates material in the 0.001 - to $0.1-\mu \mathrm{m}$ range, and reverse osmosis separates materials less than $0.001 \mu \mathrm{m}$ in size. Both microfiltration and ultrafiltration allow a high concentration of the solids in the retentate and the production of highly pure permeate. Cross-flow filters can be configured into plate-and-frame, spiral-wound, hollow-fiber, and tubular arrangements, depending on the flow requirements, solids content, required resistance to fouling, and necessary membrane surface area.

Some of the materials that possibly need to be removed from the MVST supernate may exist in colloidal form, and the ferrocyanides used for cesium removal have very small particle sizes. Settling and/or centrifugation was often not enough to remove all of the fine particulates from the treated supernate; however, filtration through submicron filters generally removed the materials and resulted in a much enhanced DF (Table 11). In order to ensure that insoluble TRU, strontium, and cobalt compounds are removed from the supernate, microfiltration or ultrafiltration may be required. Ultrafiltration has been successfully used in the United Kingdom for the cleanup of alkaline plutonium-containing effluents, improving significantly on sedimentation or centrifugation, ${ }^{21}$ and other European countries have used a method that combined ion exchange and/or chemical precipitation with ultrafiltration to obtain the needed removal efficiency. ${ }^{22,23}$ Ferrocyanide colloidal particles used for ${ }^{137} \mathrm{Cs}$ removal and formed in situ have been removed by ultrafiltration. ${ }^{24}$ Based on earlier experimental results at $\mathrm{ORNL}^{25,26}$ (the W-29 supernate used in these tests contained up to $0.5 \mathrm{wt} \%$ solids, while our studies have dealt with solutions with essentially no settleable solids) and the literature cited above, our experimental program was initiated to study filtration requirements and filter properties with various ferrocyanide slurries in both simulant and actual MVST supernate. 


\subsection{Experimental Methods}

A small, stirred-cell ultrafiltration unit was used to test the filtration rates, the particulate separation efficiencies, and the applicability of ultrafiltration to the MVST supernate. The unit was a Micro Filtration Systems model UHP43 glass-and-Teflon cell of 70-mL capacity and capable of taking 70-psi pressure. The filters were chosen on the basis of chemical resistance (stability to $\mathrm{pH}>13$ ), and the molecular weight cutoff (MWCO) was derived from work at Harwell in the United Kingdom. ${ }^{27}$ The membranes were 43 -mm-diam polysulfone ultrafiltration membranes with a 20,000 MWCO, type UK (pore size, $0.01 \mu \mathrm{m}$ ). The membranes were prepared for use by, first, installing them in the cell and, then, washing them with deionized water before adding the material to be filtered. After use, each membrane was cleaned using various solvents and acidic or basic solutions, rinsed with deionized water, and stored in deionized water until the next application.

When radioactively traced W-29 simulant was used in the ultrafiltration unit, vacuum instead of applied pressure was used to drive the filtration to prevent the spread of radioactivity in the event of an accident. Preliminary measurements of the permeate rate with distilled water using 20 to $22 \mathrm{in.} \mathrm{Hg}$ vacuum showed a rate of $0.8 \mathrm{~mL} / \mathrm{min}$. Filtering untraced simulant resulted in a lower filtration rate $(0.35 \mathrm{~mL} / \mathrm{min})$. Using 15 -psig applied pressure to the filter and vacuum on the permeate side when filtering simulant resulted in a rate of $0.45 \mathrm{~mL} / \mathrm{min}$.

\subsection{Experimental Results}

To test the removal of loaded, particulate ion-exchange material from the supernate by ultrafiltration, the ultrafiltration cell and membrane were first tested on simulant. Two tests were performed using simulant with added sodium titanate and ferrocyanide slurries to determine filtration rates, filterability, and volume reductions.

In the first test, a $500-\mathrm{mL}$ batch of W-29 simulant plus $300 \mathrm{ppm}$ sodium titanate and $115 \mathrm{ppm}$ Savannah River-method sodium nickel ferrocyanide slurry was filtered through the 20,000-MWCO ultrafiltration membrane. The filtration rate was constant at $27.5 \mathrm{~mL} / \mathrm{min}$ throughout the test, using a vacuum of 20 to $22 \mathrm{in.} \mathrm{Hg}$ to supply the differential pressure. The final permeate volume was $510.2 \mathrm{~mL}$, and $4.3 \mathrm{~mL}$ of concentrate remained in the cell for a volume reduction factor of 119.6 and a final concentration of $48,300 \mathrm{ppm}$, or about a $5 \%$ slurry. In the second test, an approximately $3.7 \%$ slurry of sodium nickel ferrocyanide was filtered on the ultrafiltration membrane with a $550-\mathrm{mm}-\mathrm{Hg}$ pressure differential. The 
suspension consisted of $2 \mathrm{~g}$ of $\mathrm{Na}_{4} \mathrm{Fe}(\mathrm{CN})_{6} \cdot 10 \mathrm{H}_{2} \mathrm{O}$ and $2.2 \mathrm{~g} \mathrm{Ni}\left(\mathrm{NO}_{3}\right)_{2} 6 \mathrm{H}_{2} \mathrm{O}$ in $14 \mathrm{~mL}$ of water, plus $100 \mathrm{~mL}$ of W-29 simulant adjusted to $\mathrm{pH} 11$. After mixing, the slurry had a $\mathrm{pH}$ of 9.75. It was filtered over a period of several days at a constant filtration rate of about 5 $\mathrm{mL}$ per hour. At the end of the test, about $9 \mathrm{~mL}$ of slurry was easily removed from the cell, and another $3.5 \mathrm{~mL}$ was removed from the walls and filter. This resulted in a volume reduction ratio of $\approx 9$ and a solids concentration of $\approx 336 \mathrm{~g} / \mathrm{L}$, or $30 \%$. The slurry was very thick and did not pour easily, but it appeared to be pumpable.

\section{REMOVAL OF ${ }^{60} \mathrm{CO}$ FROM SUPERNATE}

Additional tests were initiated to determine whether ${ }^{60} \mathrm{Co}$ could be removed from the supernate when results showed that, following the removal of ${ }^{137} \mathrm{Cs}$, it would be the primary contributor to the gamma field remaining in the supernate. Cobalt can be present in different physical and chemical forms, including colloids and anionic and neutral complexes, as well as the more common cationic species. ${ }^{28} \mathrm{~A}$ variety of ion-exchange and clarification methods were evaluated in scouting tests that were initiated just before the experimental program was interrupted.

\subsubsection{Experimental Methods}

The batch $\mathrm{K}_{\mathrm{d}}$ test methods outlined in Sect. 2.1 for ion-exchange materials and the methods described in Sect. 2.3 for the UF cell and membranes were used in these tests.

\subsubsection{Experimental Results}

In the first set of experiments, ultrafiltration was used to remove particulate ${ }^{60} \mathrm{Co}$. Ultrafiltration on a 20,000-MWCO membrane, at $\mathrm{pH} 8.5$, of the MVST W-26 supernate as received after one cycle of ferrocyanide/sodium titanate decontamination, resulted in no removal (within experimental error) of ${ }^{60} \mathrm{Co}$. The supernate was then adjusted to $\mathrm{pH} 13$ and allowed to equilibrate. Approximately $5 \%$ of the supernate volume precipitated upon $\mathrm{pH}$ adjustment. The supernate was then filtered by ultrafiltration, again with no measurable decrease in ${ }^{60} \mathrm{Co}$ activity.

A number of inorganic sorbents and organic ion-exchange materials were also tested for removal of ${ }^{60} \mathrm{Co}$ from supernate solution from MVST W-26. Residual solutions that had been used for several tests of ${ }^{137} \mathrm{Cs}$ removal from the W-26 supernate were composited and analyzed. Cesium had been removed sufficiently, using nickel or cobalt ferrocyanide 
treatment, that ${ }^{60} \mathrm{Co}$ was the dominant gamma activity (about $180 \mathrm{~Bq} / \mathrm{mL}$ ), and essentially no cobalt had been removed during these cesium-removal tests. This composite solution $(\mathrm{pH} \sim 10.2)$ was used to test a number of processes that might remove ${ }^{60} \mathrm{Co}$. The following gave no useful cobalt removal ( $\mathrm{DF}<1.25$ ):

- Addition of granular KCoFC at $\mathrm{pH} 10.2$

- Addition of $\mathrm{Co}\left(\mathrm{NO}_{3}\right)_{2}$ at $\mathrm{pH} 10.2$, and then $\mathrm{Na}_{4} \mathrm{Fe}(\mathrm{CN})_{6}$, to precipitate $\mathrm{NaCoFC}$ in situ

- Addition of $\mathrm{Co}\left(\mathrm{NO}_{3}\right)_{2}$ at $\mathrm{pH} 12.8$, and then $\mathrm{Na}_{4} \mathrm{Fe}(\mathrm{CN})_{6}$, to precipitate $\mathrm{NaCoFC}$ in situ

- Adjustment of $\mathrm{pH}$ to $\approx 1$ before addition of $\mathrm{Co}\left(\mathrm{NO}_{3}\right)_{2}$; adjustment to 7.8 before addition of $\mathrm{Na}_{4} \mathrm{Fe}(\mathrm{CN})_{6}$

- Addition of $\mathrm{Co}\left(\mathrm{NO}_{3}\right)_{2}$ at $\mathrm{pH} 1$, followed by $\mathrm{pH}$ adjustment to 10.2 or 12.8 to precipitate $\mathrm{Co}(\mathrm{OH})_{2}$

- Addition of sodium aluminate to precipitate aluminum hydroxide

- Addition of cobalt hexacyanocobaltate at $\mathrm{pH} 10.2$

- Manox $\mathrm{A}\left(\mathrm{MnO}_{2}\right.$; claimed to be a specific cobalt sorbent) at $\mathrm{pH} 10.2$

- Addition of $\mathrm{KCuFC}$ at $\mathrm{pH} 10.2$

- Addition of sodium titanate at $\mathrm{pH} 10.2$

- Addition of $\mathrm{Co}\left(\mathrm{NO}_{3}\right)_{2}$ plus TRU-Clear (potassium ferrate, strong oxidant that precipitates as $\mathrm{Fe}_{2} \mathrm{O}_{3}$ ) at $\mathrm{pH} 10.2$

- Addition of Chelex 100 at $\mathrm{pH}$ levels of $2.7,10.2$, and 12.8

- Addition of Lewatit 208 at $\mathrm{pH}$ levels of 2.7, 10.2, 12.8

- Adjustment of $\mathrm{pH}$ to $\approx 1$; addition of $\mathrm{Co}$ and $\mathrm{H}_{2} \mathrm{O}_{2}$ to try to break complex; addition of Chelex 100

- Adjustment of $\mathrm{pH}$ to $\approx 1$; addition of $\mathrm{Co}$ and $\mathrm{H}_{2} \mathrm{O}_{2}$ to try to break complex; addition of Lewatit 208

- Adjustment of $\mathrm{pH}$ to $\approx 1$; addition of $\mathrm{Co}$ and $\mathrm{H}_{2} \mathrm{O}_{2}$ to try to break complex; addition of Dowex 1

- Adjustment of pH to $\approx 1$; addition of $\mathrm{Co}$ and $\mathrm{H}_{2} \mathrm{O}_{2}$ to try to break complex; addition of Dowex 50 
Most gave no measurable DF. A few gave small DFs (up to about 1.2); these include (1) the solutions adjusted to $\mathrm{pH} \mathrm{1,} \mathrm{suggesting} \mathrm{that} \mathrm{an} \mathrm{acid} \mathrm{digestion} \mathrm{step} \mathrm{might} \mathrm{convert} \mathrm{the}$ residual cobalt to an exchangeable form; and (2) the cobalt ferrocyanides after many days of mixing, suggesting that a very slow exchange of cobalt might be occurring between the ${ }^{60} \mathrm{Co}$ in the supernate and cobait in the solid exchanger.

In summary, the data show that cobalt is not filterable even with ultrafilters of porosity corresponding to $20,000 \mathrm{MWCO}$, is not exchangeable with stable cobalt carrier over the $\mathrm{pH}$ range from 1 to 12.8 , and is not exchangeable on ion exchangers under conditions that remove normal cobalt from solution. These results suggest that the residual cobalt in the waste supernate solutions is in some nonequilibrium form, possibly an inner-sphere complex, that is not in reasonably rapid equilibrium with the "normal" species of bulk cobalt in solution under the same conditions.

\subsection{NITRATE REMOVAL}

Solid sodium nitrate is currently an acceptable solid waste form for WIPP, provided the waste meets other criteria and has a TRU composition. Thus, much of the nitrate might be incorporated in solid TRU waste that is scheduled for shipment to WIPP. However, there is more $\mathrm{NaNO}_{3}$ than required for this purpose, so less waste for shipment to WIPP would be generated if the excess could be disposed of otherwise. In the case of liquid waste, the reduction in nitrate concentration required to meet the specification for direct discharge of the treated waste to the environment $(10 \mathrm{ppm} \mathrm{N})$ is nearly $1 \times 10^{5}$ for nitrate. ${ }^{2}$ Accordingly, some consideration has been given to nitrate removal processes.

The logical options are nitrate destruction to relatively innocuous gaseous products or recovery of nitric acid for recycle. Since the quantity of nitrate present is large, nitric acid recovery would produce about $380 \mathrm{~m}^{3}(100,000 \mathrm{gal})$ of $10 \underline{\mathrm{M}} \mathrm{HNO}_{3}$. Even if it is highly decontaminated, it is not obvious that this much acid could be used effectively (via recycle) or stored conveniently for future use. The alternative is nitrate destruction to species, such as $\mathrm{N}_{2}$ or possibly $\mathrm{NH}_{3}$, that could be discharged to the atmosphere. An attractive option is to decontaminate and recover nitric acid, neutralize it, and use it for fertilizer on-site, perhaps for the grass cover over burial grounds which are already contaminated. For scoping purposes, the total amount of nitrate would provide the nitrogen requirement for about 200 acres of grass for 10 years. 
Electrolytic reduction has been investigated to a considerable extent over several decades, and there are plans to study it further in another program here. Therefore, electrolytic destruction has not been investigated. Destruction of nitrate by chemical reducing agents is commonly applied to acid wastes but is not effective with alkali-metal nitrates in neutral or alkaline solutions. Thermal denitration can be used with polyvalent metal nitrates; but, again, it is not practical with alkali-metal nitrates. Chemical and thermal denitration yield $\mathrm{NO}_{\mathrm{x}}$, which can be largely recovered as nitric acid in a fractionation column.

\subsubsection{Experimental Methods}

Three scouting tests were performed in which sulfuric acid was added to MVST W-29 waste simulant to a $\mathrm{H}_{2} \mathrm{SO}_{4} / \mathrm{NO}_{3} \cdot \mathrm{mol}$ ratio slightly above 0.5 ; a typical feed consisted of $300 \mathrm{~mL}$ of W-29 simulant mixed with $40 \mathrm{~mL}$ of concentrated $\mathrm{H}_{2} \mathrm{SO}_{4}$. The concentrate was diluted with water to yield $500 \mathrm{~mL}$. The solution was evaporated until the temperature reached the range 150 to $200^{\circ} \mathrm{C}$, and the condensate was collected in successive fractions. All samples were titrated for acid, and the concentrate and some condensate samples were analyzed for chloride.

\subsubsection{Experimental Results}

Most of the nitrate was recovered as $\mathrm{HNO}_{3}$ in the condensate, and the extent of recovery varied with the final (maximum) evaporation temperature. Nitrate left in the salt concentrate ranged from 20 to $1.3 \%$ of the total present, the lower value when an air flow was used to sweep vapors to the condenser and the final temperature was $-200^{\circ} \mathrm{C}$. It is expected that a higher nitrate removal would be achieved if a larger excess of sulfuric acid had been used. In any case, it is possible to recover nitrate in this way.

Two potential problems were encountered in the practical application of this process. One was the formation of solids in the evaporator, primarily because alkali-metal sulfates are less soluble than the corresponding nitrates. In spite of the solids, no difficulty was experienced during evaporation even when almost no liquid phase was left. After partial cooling, the addition of water completely dissolved the solid residue, yielding an alkali-metal sulfate salt solution containing the residual nitrate. In the past, sulfate solutions have had much higher release limits than nitrate solutions. If not released, the solution could be treated, for example with lime, to produce $\mathrm{NaOH}$ solution for reuse. 
The second problem resulted from the presence of chloride in the MVST simulant solutions at a concentration near $0.1 \underline{\mathrm{M}}$. The chloride evaporated with the water and nitric acid, and the chloride concentration of the condensate decreased slowly as the evaporation proceeded. Essentially all the chloride ended up in the acid product. Chloride could cause a corrosion problem in the evaporator, although, with the small size required, a quartz evaporator could readily be used. Chloride is undesirable in the nitric acid product that would presumably be used for plant operations; however, proven removal methods are available.

\section{SUMMARY}

The experimental program being conducted to investigate potential separation methods for application to specific problems relating to the management of LLLW at ORNL has been described. Measurements are reported for cesium and strontium removal from simulated high-salt wa te compositions, using both inorganic ion-exchange sorbents and organic ion-exchange resins, and for one experiment with actual LLLW supernate solution from Melton Valley Storage Tank W-26, using inorganic sorbents. The purpose of the study was to acquire an extensive data base to support the development of flowsheets for decontamination of the LLLW generated at ORNL.

Experimental measurements with inorganic ion exchange have centered on batch separations of cesium using transition-metal hexacyanoferrate(II) compositions and of strontium using titanium oxide-based sorbents. Cesium distribution coefficients in the range of $1 \times 10^{6}$ were generally observed with nickel and cobalt ferrocyanides at $\mathrm{pH}$ values $\leq 11$, yielding DFs of about 100 with 100 ppm of sorbent in a single-stage batch separation. Ferrocyanides are stable in acid solutions and remain reasonably effective as the $\mathrm{pH}$ decreases into the acid concentration range of at least 1 to $2 \underline{\mathrm{M}}$. Strontium distribution coefficients as large as $1 \times 10^{5}$ were observed with sodium titanate at $\mathrm{pH} 13$, and the values decrease as the $\mathrm{pH}$ decreases.

Most organic ion-exchange resins are not very effective for cesium removal from such high salt concentrations, but a new resorcinol-based resin developed at the Savannah River Site was found to be considerably superior to any other resin tested. An unexpected effect of resin particle size was observed, with larger resin particles showing much more effective 
cesium removal than small particles. Several chelating resins were effective for removal of strontium from the waste simulants. An ion-exchange column test successfully demonstrated the simultaneous removal of both cesium and strontium from a waste simulant solution.

The large distribution coefficients and poor physical form (degradation to small particles) of most inorganic sorbents favor their use in simple batch separation processes. Although distribution coefficients were smaller with organic resins than with the best inorganic sorbents, they were large enough, in some cases, that batch processes might be possible. However, organic resins are generally more suited to column operations, and distribution coefficients were tritirely adequate for this application.

Cross-flow filtration at the microfiltration and ultrafiltration level was investigated both for removing the suspended ferrocyanide ion-exchange material and as a means of reducing the concentration of ${ }^{60} \mathrm{Co}$ in the supernate. Tests with simulants containing NaNiFC or $\mathrm{KNiFC/sodium} \mathrm{titanate} \mathrm{slurries} \mathrm{showed} \mathrm{that} \mathrm{concentrations} \mathrm{of} \mathrm{up} \mathrm{to} 30 \%$ solids were possible. Tests of actual supernate using ion exchangers, ultrafiltration, and complex breaking reagents gave little, or no, measurable DFs. Nitrate removal was investigated using chemical denitration with sulfuric acid and resulted in the removal of greater than $98 \%$ of the nitrate from the salt solution. 


\section{REFERENCES}

1. M. B. Sears, J. L. Botts, R. N. Ceo, J. J. Ferrada, W. H. Griest, J. M. Keller, and R. J. Schenley, Sampling and Analysis of Radioactive Liquid Wastes and Sludges in the Melton Valley and Evaporator Storage Tanks at ORNL, ORNL/TM-11652, 1990.

2. D. D. Lee and D. O. Campbell, Mass Balance of Low-Level Liquid Waste Storage Tanks and Requirements for Waste Processing, ORNL/TM, in preparation.

3. J. B. Berry, D. O. Campbell, D. D. Lee, and T. L. White, "'Process Development for Remote-Handled Mixed Waste Treatment," presented at the 1990 AIChE Summer National Meeting, San Diego, Calif., August 1990.

4. International Atomic Energy Agency Report, Chemical Treatment of Low- and Intermediate-Level Aqueous Radioactive Waste, in final review (publication ssheduled in 1991).

5. E. W. Hooper, B. A. Phillips, S. P. Dagnall, and N. P. Monckton, An Assessment of the Application of Inorganic Ion Exchangers to the Treatment of Intermediate Level Wastes, AERE-R-11088, Atomic Energy Res varch Establishment, Harwell, 1984.

6. B. A. Phillips and E. W. Hooper, Study of the Behavior of Inorganic Ion Exchangers in the Treatment of Medium Active Effluents, Part I. Preliminary Experimental Work on Absorber Preparation and Performance, AERE-G-2872, Atomic Energy Research Establishment, Harwell, 1988.

7. G. W. Beaven, J. E. Cross, and E. W. Hooper, Study of the Behavior of Inorganic Ion Exchangers in the Treatment of Medium Active Effluents, Part IV. Further Studies on Absorber Performance, AERE-G-4381, Atomic Energy Research Establishment, Harwell, 1988.

8. S. D. Reilly, C. F. V. Mason, and P. H. Smith, Cobalt(III) Dicarbolide: A Potential ${ }^{137} \mathrm{Cs}$ and ${ }^{90} \mathrm{Sr}$ Waste Extraction Agent, LA-11695, $199 \mathrm{C}$.

9. E. P. Horwitz, M. L. Dietz, and D. E. Fisher, "SREX, a New Process for the Extraction and Recovery of Strontium from Acidic Nuclear Waste Streams," Solvent Extr. Ion Exch., in press.

10. E. P. Horwitz, M. L. Dietz, and D. E. Fisher, Solvent Extr. Ion Exch., $\underline{8}, 199$ (1990).

11. M. A. Ebra, R. M. Wallace, D. D. Walker, and R. A. Wille, "Tailored Ion Exchange Resins for Combined Cesium and Strontium Removal from Soluble SRP High-Level Waste," in The Scientific Basis for Nuclear Waste Management, S. V. Topp, Ed., p. 632, Elsevier, 1982. 
12. J. P. Bibler, R. M. Wallace, and L. A. Bray, "Testing a New Cesium-Specific Ion Exchange Resin for Decontamination of Alkaline High-Activity Waste," Waste Management '90, Vol. 2, R. G. Post, Ed., pp. 747-51, 1990.

13. D. O. Campbell, D. D. Lee, and T. A. Dillow, Summary Report on Process Development Studies for LLLW Treatment, Letter Report to C. H. Brown, Sept. 28, 1989.

14. D. O. Campbell, D. D. Lee, and T. A. Dillow, "Low-Level Liquid Waste Decontamination by Ion Exchange," Waste Management '90, Vol. 2, R. G. Post, Ed., pp. 389-98, 1990.

15. W. E. Prout, E. R. Russell, and H. J. Groh, "Ion Exchange Absorption of Cesium by Potassium Hexacyanocobalt(II) Ferrate(II)," J. Inorg. Nucl. Chem. 27, 473 (1965).

16. C. Loos-Neskovic, M. Fedoroff, and E. Garnier, "Preparation, Composition, and Structure of Some Nickel and Zinc Ferrocyanides: Experimental Results," Talanta $\underline{36}$, 749 (1989).

17. J. Lehto and R. Harjula, "Separation of Cesium from Nuclear Waste Solutions with Hexacyanoferrate(II)s and Ammonium Phosphomolybdate," Solvent Extr. Ion Exch. 5(2), 343-52 (1987).

18. R. G. Dosch, Final Report on the Application of Titanates, Niobates, and Tantalates to Neutralized Defense Waste Decontamination - Materials, Properties, Physical Forms, and Regeneration Techniques, SAND80-1212, 1981.

19. E. D. Coilins, D. O. Campbell, L. J. King, J. G. Knauer, and R. M. Wallace, "Evaluation of Zeolite Mixtures for Decontaminating High-Activity-Level Water at the Three Mile Island Unit 2 Nuclear Power Station," pp. 43-51 in Inorganic Ion Exchangers and Adsorbents for Chemical Processing in the Nuclear Fuel Cycle, IAEA-TECDOC-337, 1985.

20. P. S. Cartwright, "Pollution Control Membranes: Continuous, Competitive, Clean," Chem. Proc., pp. 23-30 (July 1990).

21. P. Biddle and R. G. Gutman, Use of Ultrafiltration for the Cleanup of Alkaline PuContaining Effluents, AERE-R-10942, Atomic Energy Research Establishment, Harwell, 1983.

22. R. G. Gutman, I. W. Cumming, and G. H. Williams, Active Liquid Treatment by a Combination of Precipitation and Membrane Processes, EUR-10822, Commission of the European Communities, Luxembourg, 1986.

23. L. Cecille, I. W. Cumming, G. Gasparini, and J. F. Dozol, New Alternative Processes for the Treatment of the Alkaline Solvent Wash Waste, CEA-CONG-8759, Centre d'Etudes Nucleaires de Cadarache, France, 1986. 
24. V. T. Le, L. P. Buckley, and G. J. McConeghy, Selective Removal of Dissolved Radioactivity from Aqueous Wastes by a Chemical Treatment/Ultrafiltration Technique, Proc. 2nd Int. Conf. Sep. Sci. Technol., Vol. 2, pp. 640-46, Can. Soc. Chem. Eng., Ottawa, Ont., 1989.

25. V. L. Fowler and J. D. Hewitt, Filtration of Oak Ridge National Laboratory Simulated Liquid Low-Level Waste, ORNL/TM-10653, 1989.

26. V. L. Fowler and J. D. Hewitt, Cross-Flow Filtration of Oak Ridge National Laboratory Liquid Low-Level Waste, ORNL/TM-10742, 1989.

27. J. E. Cross and E. W. Hooper, "Advanced Methods for the Removal of Actinides from Low and Intermediate Level Waste Effluents," Waste Management '89, Tucson, Ariz., 1989.

28. P. J. Durrant and B. Durrant, Introduction to Advanced Inorganic Chemistry, 2nd ed., John Wiley \& Sons, Inc., New York, $19 \%$. 


\section{INTERNAL DISTRIBUTION}

1. H. L. Adair

2. J. M. Begovich

3. J. T. Bell

4. J. B. Berry

5. W. D. Bond

6. C. H. Brown, Jr.

7. D. O. Campbell

8. R. M. Canon

9. E. D. Collins

10. K. W. Cook

11. A. G. Croff

12. T. A. Dillow

13. S. M. DePaoli

14. C. P. East

15. W. Fulkerson

16. R. K. Genung

17. I. R. Hightower

18. L. Holder

19. E. K. Johnson

20. C. M. Kendrick

21. T. E. Kent

22. K. H. King-Jones

23. J. R. Lawson

$\begin{aligned} \text { 24-25. } & \text { D. D. Lee } \\ 26 . & \text { J. J. Maddox } \\ 27 . & \text { R. C. Mason } \\ 28 . & \text { A. J. Mattus } \\ 29 . & \text { L. E. McNeese } \\ 30 . & \text { L. J. Mezga } \\ 31 . & \text { J. J. Perona } \\ 32 . & \text { D. J. Peterson } \\ 33 . & \text { D. J. Pruett } \\ 34 . & \text { S. M. Robinson } \\ 35 . & \text { T. F. Scanlan } \\ 36 . & \text { C. B. Scott } \\ 37 . & \text { M. G. Stewart } \\ 38 . & \text { P. A. Taylor } \\ 39 . & \text { J. F. Trabalka } \\ 40 . & \text { D. W. Turner } \\ 41 . & \text { E. L. Youngblood } \\ 42 . & \text { Cen. Res. Library } \\ 43 . & \text { Doc. Ref. Section } \\ 44 . & \text { Lab Records } \\ 45 . & \text { Lab Records, R.C. } \\ 46 . & \text { ORNL Pat. Sect. }\end{aligned}$

\section{EXTERNAL DISTRIBUTION}

47. Office of Assistant Manager, Energy Research and Development, DOE-OR, F. O. Box 2001, Oak Ridge, TN 37831-8600

48-57. Office of Scientific and Technical Information, P. O. Box 62, Oak Ridge, TN 37831 
$-$
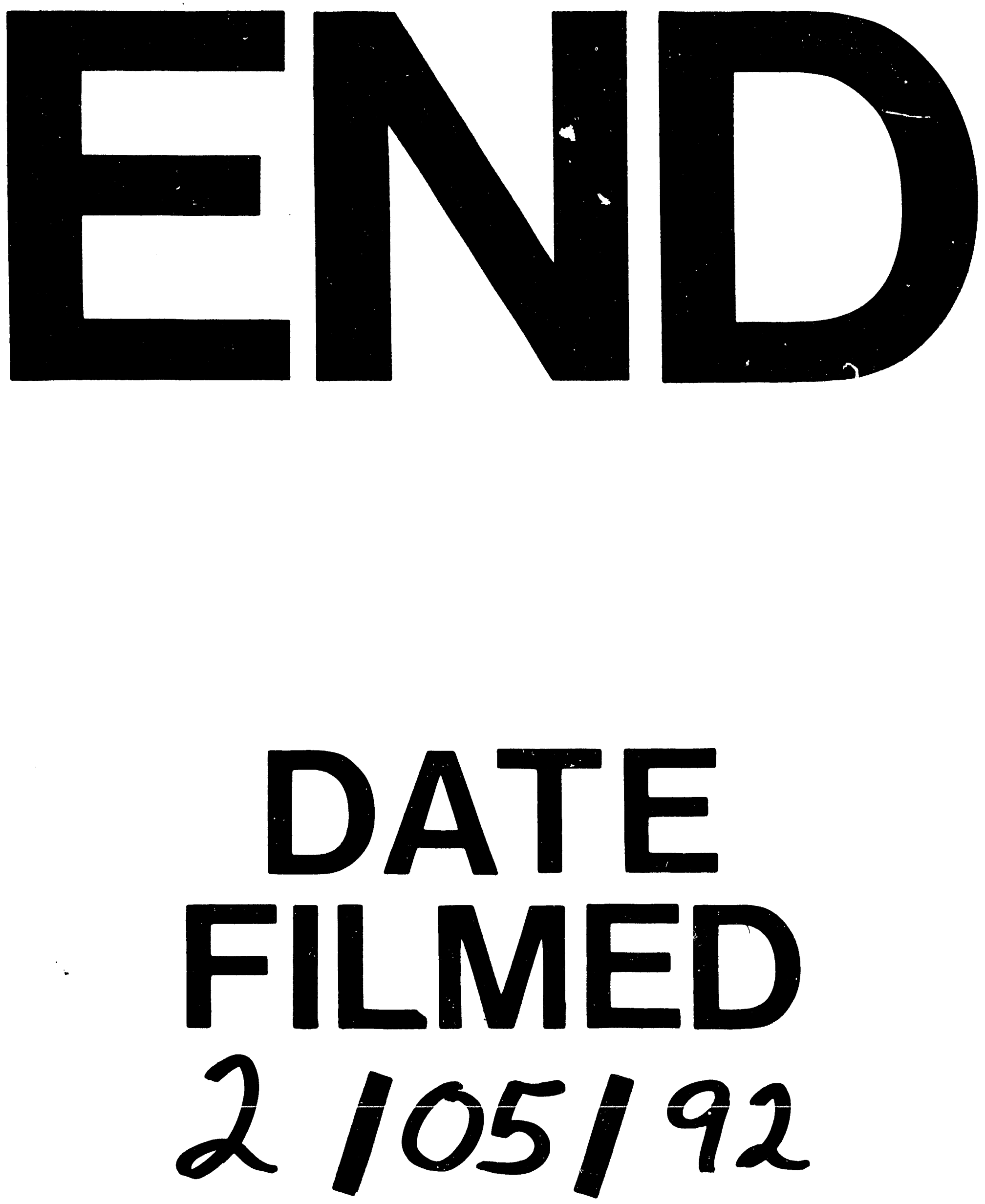